
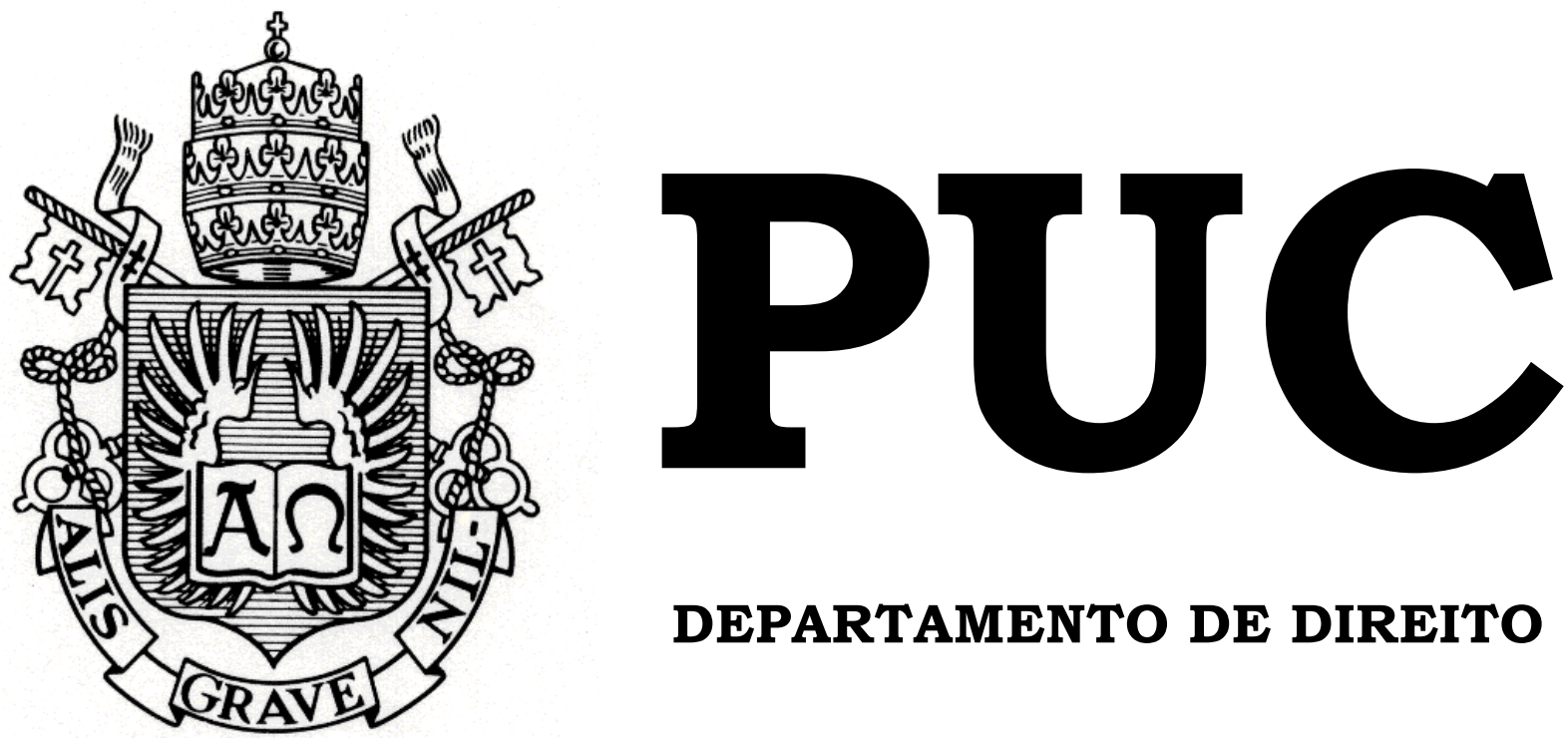

DEPARTAMENTO DE DIREITO

RESPONSABILIDADE CIVIL NAS REDES SOCIAIS. UMA ANÁLISE DO ESTADO ATUAL DA DOUTRINA E JURISPRUDÊNCIA.

por

MARIANA DE MORAES PALMEIRA

ORIENTADOR: CARLOS AFFONSO PEREIRA DE SOUZA

2011.1 
PONTIFÍCIA UNIVERSIDADE CATÓLICA DO RIO DE JANEIRO

RUA MARQUÊS DE SÃO VICENTE, 225 - CEP 22453-900

RIO DE JANEIRO - BRASIL

\section{RESPONSABILIDADE CIVIL NAS REDES SOCIAIS. UMA ANÁLISE DO ESTADO ATUAL DA DOUTRINA E JURISPRUDÊNCIA.}

\section{por}

\section{MARIANA DE MORAES PALMEIRA}

Monografia apresentada ao

Departamento de Direito da Pontificia Universidade Católica do Rio de Janeiro (PUC-Rio) para a obtenção do Título de Bacharel em Direito.

Orientador: CARLOS AFFONSO PEREIRA DE SOUZA 
"A vida só pode ser compreendida olhando-se para trás; mas só pode ser vivida olhando-se para a frente. "

- Kierkegaard 
Maria Clara e Olivia

Para elas, por tudo e para sempre. 


\section{Agradecimentos}

Ao Toth, por sempre estar ao meu lado.

"When the night has come

And the land is dark

And the moon is the only light we'll see

No I won't be afraid, no I won't be afraid

Just as long as you stand, stand by me"

Aos meus pais, Sonia e Fred, pelo apoio fundamental com as crianças sem o qual tudo teria sido muito mais difícil.

A Ju, meu braço direito, por cuidar das crianças com tanto carinho e dedicação enquanto eu estudava.

Aos amigos e professores que compartilharam esses anos de curso comigo, em especial à Sarah pela amizade e pela ajuda de sempre.

Ao professor Carlos Affonso Pereira de Souza pela possibilidade de escolha de um tema tão atual e instigante. 


\section{Resumo}

A proposta do presente trabalho é estudar a doutrina e a jurisprudência no que tange a responsabilização dos sites de redes sociais. Discute-se como o desenvolvimento deste novo negócio no ambiente da Internet ao longo da primeira década do século XXI impacta as teorias de reponsabilidade civil. Busca-se entender como os Tribunais julgam as frequentes ações de indenização ajuizadas em face dos provedores de serviços de Internet, e especificamente como entendem a questão relacionada à responsabilidade por fato de terceiro. Por fim, discute-se o anteprojeto de lei que visa criar o marco civil da Internet no Brasil. 


\begin{abstract}
The purpose of this paper is to analyze case law regarding the liability of social networks websites. For this matter, it will be discussed the development of the "social networking» business in the Internet environment over the last decade impacting the main concepts regarding civil liability theories. The present study also seeks to understand how actions for damages filed against the online services providers are judged by Brazilian courts and specifically how justices understand the issue related to third party liability. Finally, this paper analyzes the bill of law proposition/draft that aims to create the Civil Framework Internet in Brazil.
\end{abstract}




\section{Palavras-Chave}

Internet. Provedores de Serviços de Internet. Redes Sociais.

Responsabilidade Civil. Responsabilidade por fato de terceiro. Marco Regulatório. Marco Civil da Internet no Brasil. 


\section{Sumário}

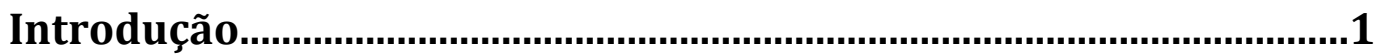

1. A Configuração da Responsabilidade Civil em Redes Sociais................10

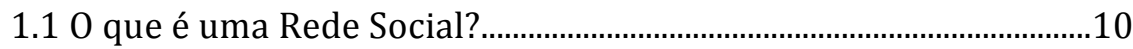

1.2 Problemas Jurídicos das Redes Sociais.................................................15

1.3 Responsabilidade do Provedor de Serviços de Internet por Ato

de Terceiro: Breve Resumo dos Caminhos Apontados pela

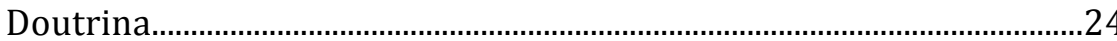

1.4 A Experiência Internacional em Casos de Responsabilidade Civil

em Redes Sociais.......................................................................................28

2. A Análise da Jurisprudência Brasileira Sobre Responsabilidade Civil em Redes Sociais....................................................................... 37

2.1 A Não Responsabilização: O Provedor como Mero Intermediário .38

2.2 A Afirmação da Responsabilidade Civil Subjetiva

2.3 A Responsabilidade Objetiva do Provedor.

2.3.1 CDC e a Decisão do STJ sobre o Orkut

2.3.2 A Teoria do Risco: Parágrafo Único do Artigo 927, CC.56

3. A Experiência do Marco Civil da Internet Brasil...........................62

3.1 0 Processo de Criação de um Marco Legal para a Internet............62

3.2 A Responsabilidade Civil em Redes Sociais no Marco Civil..........69

3.2.1 A antiga redação do artigo 20 e suas críticas...................69

3.2.2 A nova redação do artigo 20 (ordem judicial) e comentários relevantes postados no portal colaborativo.....73

4. Conclusão 79

5. Bibliografia. 


\section{Introdução}

“O Brasil é considerado o pais mais sociável do mundo". É com esta frase que a revista Época de 27 de maio de 2010 abre uma reportagem especial sobre o avanço das redes sociais no Brasil. ${ }^{1}$ Dados do Ibope citados na matéria mostram que o pais está entre os 10 maiores usuários de redes sociais, e que o número de contatos (amigos) de cada usuário no Brasil é superior a média mundial.

A referida pesquisa realizada em 2010 apontou que $80 \%$ dos usuários de Internet no Brasil tem perfil em algum site de rede social, a exemplo de Orkut, Facebook, ou Twitter. Outro estudo também do Ibope ${ }^{2}$, divulgado em 18/03/2011, revela que há no pais 73,9 milhões de usuários de Internet, portanto, perto de 60 milhões de pessoas no Brasil fazem uso das redes sociais.

A rede social que mais reúne usuários no Brasil é o Orkut. Criada em 2004 por Orkut Büyükkökten, o Orkut caiu no gosto do brasileiro em 2005 com sua versão traduzida para o português. A exemplo do Orkut, o Facebook também funciona por meio de perfis e comunidades e é hoje a rede social de maior número de usuários no mundo. Segundo dados do próprio site ${ }^{3}$, são mais de 500 milhões de pessoas usando o sistema, sendo que 13 milhões apenas no Brasil.

Dados de diversos institutos de pesquisa em Internet apontam o sucesso do Orkut no Brasil, ao mesmo tempo em que começam a mostrar a escalada do Facebook no pais. Em março de 2011 o Facebook registrou um

1 http://revistaepoca.globo.com/Revista/Epoca/0,EMI143701-15224,00ONDE+OS+BRASILEIROS+SE+ENCONTRAM.html. Acesso em 25/03/2011.

${ }^{2} \mathrm{httn} / / \mathrm{www}$ ihone com hr Acesso em 2.5/03/7011 
avanço significativo: atingiu a marca de mais da metade dos usuários do Orkut. $^{4}$

Alguns exemplos comparativos entre as duas redes sociais mais famosas do Brasil podem ser indicados. Em novembro de 2010, segundo o ComScore $^{5}$, de cada quatro internautas brasileiros, três acessavam o Orkut, e apenas um acessava o Facebook. De acordo com o instituto Alexa ${ }^{6}$ nos três primeiros meses de 2011 o Orkut foi $4^{\circ}$ site mais visitado no Brasil ficando atrás do site da Google Brasil, da Google e do YouTube. Em 2004 a participação de brasileiros no Orkut ficava em torno de 5\%, já em 2011 segundo o próprio Orkut $^{7}$ os brasileiros representam mais de $50 \%$ dos usuários do site.

O Facebook cresceu no Brasil em 2010 mais de 250\% (duzentos e cinquenta por cento) segundo o instituto ComScore, mas ainda está longe dos mais de 30 milhões de usuários do Orkut. De acordo com o site socialbakers $^{8}$ entre outubro de 2010 e março de 2011 o Facebook mais do que dobrou seu número de usuários no Brasil.

A adoção de um ou outro site de rede social segundo Danah M Boyd $^{9}$, do Berkman Center for Internet and Society, da Universidade de Harvard $^{10}$, revela a presença de segmentação social também neste ambiente. Seu estudo avaliou padrões de filiação ao My Space em oposição ao Facebook que podem ser comparados ao que vem ocorrendo no Brasil com Orkut e Facebook.

\footnotetext{
$4 \quad$ http://g1.globo.com/tecnologia/noticia/2011/03/facebook-supera-metade-do-numero-devisitantes-do-orkut-no-brasil.html. Acesso em 31/03/2011.

${ }^{5}$ www.comscore.com. Acesso em 31/03/2011.

6 www.alexa.com. Acesso em 31/03/2011.

7 www.orkut.com. Acesso em 31/03/2011.

${ }^{8}$ www.socialbakers.com. Acesso em 31/03/2011.

9 Boyd, D. M., \& Ellison, N. B. (2007). Social network sites: Definition, history, and scholarship. Inurnal of Comnuter-Mediated Communication 13(1) article 11
} 
Para tanto cita pesquisa feita pela $\mathrm{FGV}^{11}$ que revela a preferência pelo Facebook em detrimento do Orkut pelas classes sociais mais altas no Brasil. Uma das possíveis razões para a elitização do Facebook no Brasil segundo matéria da The Economist ${ }^{12}$ está no fato das classes sociais mais altas terem mais amigos fora do país o que tornaria o facebook mais atraente.

O fato do Orkut no Brasil apresentar maior crescimento entre as classes sociais mais baixas gerou expressões pejorativas como "favelização do Orkut" e "orkutização". Este último termo foi usado, por exemplo, para classificar o evento "cala a boca Galvão""13 ocorrido durante a Copa do Mundo de 2010, quando milhões de usuários do Twitter irritados com a performance do locutor Galvão Bueno fizeram que a expressão fosse um dos assuntos mais comentados da rede social em questão.

Outro exemplo de como o Orkut vem sendo associado às classe sociais mais baixas é um aplicativo do Facebook chamado "Grosseria do dia" que oferece frases ou citações grosseiras como adverte o próprio nome. Uma das grosserias diz o seguinte: "Por que você não ficou no Orkut junto com os pobres?"14

Questões de ordem socioeconômica e de segmentação de público alvo à parte, é certo que o mercado de redes sociais se desenvolve a passos largos no Brasil e acaba por gerar impactos em diversas esferas, inclusive na esfera jurídica. É neste contexto que se insere o presente trabalho, ao buscar analisar como o judiciário brasileiro vem lidando com os inúmeros casos de responsabilidade civil na Internet, mais especificamente nas redes

${ }^{11} \mathrm{http}: / /$ www.economist.com/node/16943885?story id=16943885\&CFID=160302167\&CFTOKE $\mathrm{N}=85529361$. Acesso em 31/03/2011.

${ }_{12} \mathrm{http}: / / \mathrm{www}$. economist.com/node/16943885? story id=16943885\&CFID=160302167\&CFTOKE $\mathrm{N}=85529361$. Acesso em 31/03/2011.

13 http://oglobo.globo.com/pais/noblat/posts/2010/06/11/sucesso-mundial-cala-boca-galvao2.99364 asn Acesso em 31/03/2011 
sociais. Um cenário até o presente momento que carece de legislação específica capaz de oferecer segurança jurídica para todos os envolvidos hoje de alguma forma no ambiente de Internet.

O impacto sobre os direitos personalíssimos é uma das facetas que o desenvolvimento da Internet trouxe para o Direito, que, para usar a expressão de Antonio Jeová dos Santos, ainda em 2001"15 "se agiganta" com o crescente uso das redes sociais. Questões relacionadas a privacidade, imagem, honra, pedofilia, para citar alguns exemplos estão na ordem do dia.

Os casos se repetem no noticiário especializado: usuários que se deparam com ofensas a suas imagens em páginas de redes sociais, comunidades dedicadas a temas ilícitos, clonagem de perfil, e vídeos de natureza íntima postados no YouTube.

Para Ronaldo Lemos a ausência de legislação específica para tratar das novas questões trazidas pelo desenvolvimento da Internet ao mundo jurídico, acaba por transferir ao judiciário o papel de encontrar o ponto de equilíbrio dos interesses presentes na rede. ${ }^{16}$

No âmbito dos sites colaborativos, ou seja, aqueles em que os próprios usuários colocam o conteúdo, a exemplo do YouTube e dos já citados exemplos de redes sociais Orkut e Facebook, o judiciário vem experimentando um crescente volume de processos a eles relacionados. $\mathrm{O}$ Orkut apesar dos números mostrarem uma certa estagnação em seu crescimento, continua fazendo com que a Google, empresa responsável por 
sua exploração, responda a uma série de ações indenizatórias em todo o Brasil. $^{17}$

A jurisprudência até o presente momento se mostra indefinida quanto ao tipo responsabilização que deve ser imposta as partes envolvidas, em especial quanto a situação provedor de serviço de Internet frente a ato de terceiro. É evidente a divisão encontrada nos julgados:

"Enquanto a jurisprudência vacila entre responsabilizar os provedores ora objetivamente (seja com base na teoria do risco, seja com base no Código de Defesa do Consumidor), ora subjetivamente (buscando a afirmação de culpa ou falha no dever de cuidado), tantas outras decisões optam por reconhecer que o provedor é mero intermediário e que não cabe responsabilizá-lo em casos de conteúdo criado por terceiro (geralmente um usuário do site em questão)". ${ }^{18}$

Abaixo, dois exemplos do ano de 2010 ilustram a tamanha incerteza jurídica que hoje permeia a responsabilidade civil na Internet.

No Rio de Janeiro, em dezembro de 2010, o TJRJ manteve sentença de $1^{\text {a }}$ instância que condenou a Google Brasil ao pagamento de R\$ 8 mil a título de danos morais por criação de perfil falso no Orkut onde figurava a foto e o nome do autor da ação. Na foto o autor aparecia com um boné onde se lia "gay". O entendimento da desembargadora Helena Candida Lisboa Gaede é de que prevalece a aplicação do CDC e da responsabilização objetiva da empresa ré, como se lê em seu voto:

“Aplica-se à Ré, portanto, o disposto no Código de Defesa do Consumidor, incidindo na hipótese o disposto no art. 14 desta Lei, sendo objetiva a sua responsabilidade, bastando que seja demonstrada a existência da conduta, dano e do nexo de causalidade entre esses elementos". ${ }^{19}$

17 http://www.conjur.com.br/2011-jan-06/retrospectiva-2010-usar-processo-eletronico-tarefaexploratoria. Acesso em 25/03/2011.

18 Carlos Affonso Pereira de Souza, Marília Maciel e Pedro Augusto Francisco. Marco Civil da Internot· uma auestão de nrincínio in $\mathrm{httn} \cdot / / \mathrm{www}$ nunef oro $\mathrm{hr} / \mathrm{9a}=\mathrm{node} / 48$ 
Em sentindo contrário, sobre o mesmo tema, criação de perfil falso com conteúdo difamatório, é a decisão também em sede de apelação do TJRS que afirma ser de consumo a relação entre o autor da ação e a Google, porém afasta no caso concreto o dever de indenizar por parte do provedor de serviços. O desembargador Jorge Luiz Lopes do Canto ressalta que a Google opera o serviço de hospedagem por meio do Orkut, e por este motivo a forma de responsabilidade é subjetiva. Neste caso, seria necessário que o autor provasse a notificação feita à parte ré sobre a existência do material a ser impugnado:

"O autor não trouxe qualquer adminículo de prova de que noticiou ao réu a ocorrência do evento danoso noticiado na exordial, possibilitando que este tomasse as medidas cabíveis para coibi-lo", ${ }^{20}$

Por fim, um caso emblemático ocorrido em 2007, que envolvia o pedido de retirada de conteúdo da rede, revela como a ausência de legislação específica e a indefinição da jurisprudência podem causar desde prejuízos reais aos envolvidos até constrangimentos ao sistema judiciário como um todo.

Daniela Cicarelli, modelo com ampla exposição na mídia nacional, e seu namorado, Renato Malzoni Filho, foram flagrados desfrutando de momentos íntimos no mar da Espanha. As cenas foram expostas no Youtube e consequentemente vistas e revistas por um número elevado de pessoas.

Com o objetivo de fazerem com que os vídeos fossem rapidamente retirados de circulação, Cicarelli e Malzoni ingressaram com ações judiciais em face do YouTube Inc, na época a operadora do YouTube, as Organizações Globo e o Internet Group (IG). O Tribunal de Justiça do estado de São Paulo, em sede de agravo de instrumento, concedeu liminar 
para que o vídeo fosse retirado de dos sites já mencionados sob pena de multa diária de $\mathrm{R} \$ 250$ mil. $^{21}$

No entanto, cumprir a decisão judicial para o YouTube não era uma questão trivial. ${ }^{22} \mathrm{O}$ YouTube é um site colaborativo, o que significa dizer que o material inserido em suas páginas é de livre escolha dos seus usuários, e postado por upload direto, isto é: sem interferência do site.

A retirada de conteúdo do YouTube não estava apenas condicionada a simples varredura de todos os vídeos que lá estavam hospedados, mas também a certeza de que nenhum usuário do site postaria novamente o mesmo material. Como afirmam os autores anteriormente citados: “...para garantir a efetividade à decisão judicial não basta o recurso aos mecanismos tecnológicos atualmente disponíveis...". 23

Como o vídeo em questão não foi totalmente excluído do YouTube pela impossibilidade técnica que a configuração de um site colaborativo demonstra ter nestes casos, a solução encontrada pela $4^{\mathrm{a}}$ Câmara de Direito Privado do Tribunal de Justiça do Estado de São Paulo foi a concessão de uma liminar em favor dos autores do processo para que o site como um todo fosse bloqueado. ${ }^{24}$

Esta operação de bloqueio do YouTube que envolveu os provedores de backbone ${ }^{25}$ de Internet no Brasil não só deixou aproximadamente 5 milhões de internautas temporariamente sem acesso ao referido site, como

\footnotetext{
${ }^{21} \mathrm{http}: / /$ www.conjur.com.br/2008-jun-13/tj-sp proibe youtube exibir video cicarelli. Acesso em 31/03/2011.

${ }^{22}$ Carlos Affonso Pereira de Souza; Pedro de Paranaguá Moniz; Sergio Branco Vieira Junior. Neutralidade da Rede, Filtragem de Conteúdo e Interesse Público: Reflexões sobre o bloqueio do site YouTube no Brasil. in Revista de Direito Administrativo no 246 (set-dez/07); pp.50/78 23 Ibid; p.2.

24 http://www.conjur.com.br/2007-jun-28/youtube impedir acesso video cicarelli?pagina=2. Acessn em 01/04/7011
} 
também foi fonte de muita polêmica na imprensa ${ }^{26}$ bem como gerou controvérsias na interpretação da decisão do desembargador. ${ }^{27}$

A referida decisão traz trecho de suma importância para a contextualização do atual panorama das questões que envolvem Internet e responsabilidade civil no Brasil: o desembargador Ênio Santarelli Zuliani afirma que a polêmica repercussão do caso era algo natural por se tratar de “questão pioneira, sem apoio legislativo". ${ }^{28}$

Em descompasso com a experiência internacional, o cenário legal da Internet no Brasil ainda está restrito a aplicação de regras gerais ou daquelas provenientes de outras áreas do Direto, o que acaba produzindo decisões desconcertantemente paradoxais: "As decisões são tomadas com base em regras gerais o que faz com que sentenças controversas sejam proferidas com frequência”. ${ }^{29}$

Nos Estados Unidos a regulamentação para a responsabilidade civil na Internet está em parte no Communications Decency Act de 1996 e em parte do Digital Millennium Copyright Act de 1998. Já na União Europeia as regras são encontradas nas Diretivas 2000/31/CE e 2001/29/CE. Em comum os dois sistemas legais aplicam as normas de acordo com as atividades desenvolvidas pelos atores envolvidos no ambiente digital. Em contraposição à necessidade por ordem judicial para remoção de conteúdo ilícito imposta pelas regras da Comunidade Europeia, os EUA adotam um procedimento mais ágil chamado de "notice and take down".

No cenário nacional o que há de mais atual é o anteprojeto de lei para a regulamentação do uso da Internet: uma proposta colaborativa que

26 http://computerworld.uol.com.br/telecom/2007/01/09/idgnoticia.2007-01-09.2483374113/ Acesso em 01/04/2011.

${ }^{27} \mathrm{http}: / /$ idgnow.uol.com.br/Internet/2007/01/04/idgnoticia.2007-01-04.0064595137/ Acesso em $01 / 04 / 2011$.

${ }^{28}$ Carlos Affonso Pereira de Souza; Pedro de Paranaguá Moniz; Sergio Branco Vieira Junior. Op. Cit $n 3$ 
envolveu diferentes participantes interessados na normatização do ambiente de Internet. Usuários, acadêmicos, iniciativa privada, parlamentares e representantes do governo participaram entre outubro de 2009 e junho de 2010 do desenvolvimento da minuta do anteprojeto do Marco Civil da Internet no Brasil. ${ }^{30}$

É neste contexto de carência de legislação específica capaz de unificar a jurisprudência, e oferecer segurança jurídica a todos os atores que de alguma forma participam do mercado de Internet no Brasil que se insere o presente trabalho. 


\section{A Configuração da Responsabilidade Civil em Redes Sociais}

\subsection{O que é uma rede social?}

Há no mercado uma certa indiscriminariedade no uso dos termos rede social e mídia social. No entanto, são noções diferentes. Mídia social é o gênero e os sites de rede social representam uma de suas espécies.

Lusk define as mídias sociais como um aspecto da Internet que permite criar e publicar conteúdo online, compartilhar o conteúdo, e promover interação sobre este conteúdo. Elenca os diferentes tipos de mídias sociais: Sites de redes sociais (Facebook, Orkut, Linkedin etc), blogs e microblogs (Twitter), sites que permitem o compartilhamento de fotos e vídeos (Flickr, YouTube), jogos online, mundos virtuais (Second Life). ${ }^{31}$

O entendimento do que é um site de rede social parte de dois fatores básicos:

"Fundamentalmente, uma rede social é compreendida como um conjunto de dois elementos: atores (pessoas, instituições ou grupos) e suas conexões (Wasserman e Faust, 1994, Degenne e Forsé, 1999). Essas conexões são entendidas como os laços e relações sociais que ligam as pessoas através da interação social" ${ }^{32}$

Dana Boyd e Nicolle Ellison ${ }^{33}$ apontam três requisitos para a configuração de um site de rede social a partir da perspectiva do usuário: (1) criação de um perfil público ou parcialmente público; (2) articulação de uma lista de contatos com quem se está conectado; e (3) ter acesso podendo

\footnotetext{
${ }^{31}$ Lusk, Brooke. Digital Natives and Social Media Behaviors: An Overview. The Prevention Researcher, 17(December) 2010, pp 3-6. p. 4.

${ }^{32}$ Recuero, Raquel da Cunha. Em busca de um modelo para o estudo das comunidades virtuais no ciberespaço. Trabalho apresentado no XXVIII INTERCOM, em setembro de 2005, Rio de Ianeirn
} 
“cruzar" informações das conexões dos usuários de sua lista de contatos. Este ultimo ponto é para Boyd e Elisson a característica fundamental e singular dos sites de rede social, qual seja: a possibilidade de articulação da rede pessoal de contatos dando visibilidade a ela.

O primeiro site de rede social que apresentou os elementos de perfil, lista de contatos e exposição, foi SixDegrees.com. Lançado em 1997 e tendo durado até o ano 2000, a ele se sucederam uma série de sites dentro da mesma proposta de conexão e exposição. Além dos populares Facebook, Orkut ou Linkedin para citar os mais conhecidos no Brasil, há os sites de redes sociais segmentados por assunto.

Interessados em viajar o mundo dormindo no sofá dos outros acessam o Couchsurfing ${ }^{34}$, que se apresenta como a rede social para fazer conexões entre aqueles que viajam e as respectivas comunidades locais ${ }^{35}$. Um guia visual para a boa comida e onde encontrá-la é o lema do Foodspotting ${ }^{36}$, uma rede social com mais de 450 mil pessoas cadastradas. Usuários podem montar suas árvores genealógicas na rede social Meusparentes, lançada em 2007 na Alemanhã e hoje com versões em 14 idiomas. ${ }^{37}$

A grande quantidade de sites de redes sociais lançados a partir de 2003, de acordo com Boyd e Ellison ${ }^{38}$, fez com que Clay Shirky, analista do mercado de Internet, se referisse a esta explosão como YASNS: "Yet Another Social Networking Service" (mais uma rede social). O fenômeno não ficou restrito aos Estados Unidos, países de culturas tão diversas como Brasil, India, Inglaterra, Suécia, Austrália, Japão, e até mesmo China,

\footnotetext{
${ }^{34} \mathrm{http}: / /$ www.couchsurfing.org. Acesso em 10/04/2011.

35 tradução livre para: CouchSurfing is a worldwide network for making connections between travelers and the local communities they visit. Acesso em 10/04/2011.

${ }^{36} \mathrm{http}: / / \mathrm{www}$.foodspotting.com/about/press. Acesso em 10/04/2011.

${ }^{37} \mathrm{http}: / /$ www.meusparentes.com.br/Start.action. Acesso em 10/04/2011.

38 Bovd D M \& F.llison N B (O007) On cit
} 
partiram para a adoção das redes sociais.

Para melhor explicar o conceito de rede social, Kaplan e Haenlein ${ }^{39}$ partem das noções de Web 2.0 e de Conteúdo Gerado pelo Usuário - UGC. Nesse sentido, "Web 2.0" poderia ser caracterizada como a utilização da Internet como uma plataforma colabrativa para o desenvolvimento de aplicativos e conteúdos que podem ser constantemente modificados pelos usuários finais. Já a modalidade "Conteúdo Gerado pelo Usuário (UGC)" corresponderia ao somatário das formas pelas quais os indivíduos usam as redes sociais.

Da junção dos conceitos de web 2.0 e de UGC, Kaplan e Haenlein afirmam que rede social é um conjunto de sistemas baseado em Internet que toma como fundamento a tecnologia e ideologia da Web 2.0, e que permite a criação e a troca de conteúdo gerado pelo usuário (UGC). ${ }^{40}$

Colaboração é a palavra chave por trás da Web 2.0, e o exemplo mais real da cultura colaborativa na Internet completou 10 anos em janeiro de 2011: a Wikipedia. A enciclopédia feita pelos mais de 80 mil usuários seus editores em 270 idiomas. $^{41} \mathrm{~A}$ web 2.0 não é uma nova versão da Internet, mas sim uma nova forma de uso da Internet por usuários e desenvolvedores. ${ }^{42} \mathrm{~A}$ mudança mais significativa não está na tecnologia, mas no uso que é feito dela.

O ambiente interativo da web 2.0 gerou grande impacto no conteúdo dos websites ao dar ao usuário a possibilidade de participar, seja

\footnotetext{
${ }^{39}$ Kaplan, Andreas M; Haenlein, Michael. Users of the world, unite! The challenges and opportunities of social media. In: Business Horizons. Vol 53, Issue 1 (jan-feb 2010) Pp. 59-68. P. 60.

${ }^{40}$ Tradução livre para: Social Media is a group of Internet-based applications that build on the ideological and technological foundations of Web 2.0, and that allow the creation and exchange of User Generated Content.

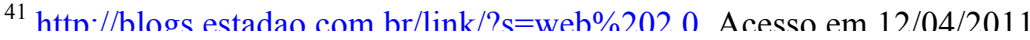


produzindo conteúdo, seja comentando ou avaliando o conteúdo já existente. Os sites de rede social estão na essência da web 2.0: vídeos postados no YouTube, comentários em blogs, botões de curtir no Facebook, scraps em álbus de fotos do Orkut, avaliações de consumidores na Amazon.com, entre outras atividades de interação.

A forma como os indivíduos interagem neste ambiente de web 2.0 não é uniforme. Charlene Li definiu uma "pirâmide de engajamento" que apresenta uma escala de participação dividida em 5 níveis, a saber: (I) na base da pirâmide os expectadores, aqueles que leem blogs ou assistem a vídeos no Youtube, (II) um nível acima dos expectadores estão os usuários que compartilham conteúdo sejam fotos, vídeos ou links, (III) numa etapa mais elevada o usuário comenta em blogs, participa de grupos de discussão, e avalia produtos em sites de compras por exemplo, (IV) quase no topo da pirâmide aqueles que efetivamente produzem conteúdo, escrevem em blogs, criam e compartilham vídeos e apresentações, e (V) os mais participativos classificados pela autora como os curadores: usuários que escrevem em wikis, moderam foruns, e lançam discussões na web. ${ }^{43}$

Em março de 2011 uma consumidora insatisfeita, representante da classe dos "muito engajados" de acordo com a classificação de Charlene Li, deu mais uma demostração da força da web 2.0 e do seu impacto nas relações jurídicas. Depois de mais de três anos de espera e conversas com a Renault tentando trocar um carro com defeito, a consumidora criou o site meucarrofalha.com.br ${ }^{44}$ onde relatou o histórico da sua situação junto à fabricante do veículo. Além do site, também criou perfis no facebook ${ }^{45}$ e no twitter $^{46}$ onde fornecia as últimas notícias sobre o litígio.

43 http://exame.abril.com.br/rede-de-blogs/midias-sociais/2010/06/29/os-desafios-das-marcas-naweb-2-0/\#more-86. Acesso em 10/03/2011.

${ }^{44} \mathrm{http}: / / \mathrm{www} \cdot \mathrm{meu}$ carrofalha.com.br/arquivos internos/index.php. Acesso em 12/04/2011.

${ }^{45}$ http://www.facebook.com/profile.php?id=1712508981\#!/profile.php?id=100002066918736\&sk= info Acesso em 10/03/7011 
O vídeo no YouTube obteve mais de 100 mil acessos, a página no twitter contabilizou 2.691 seguidores, e o perfil no Facebook onde a se lê: resolvi criar meu endereço neste espaço para que nenhum outro consumidor seja prejudicado pela Renault como eu fui. Para saber mais, acesse www.meucarrofalha.com.br arrematou 473 amigos.

A Renault, temerosa de que as iniciativas da consumidora provocassem desgaste na imagem de sua marca, ajuizou ação demandando a retirada da Internet de todo conteúdo supracitado. O juiz da $1^{\text {a }}$ Vara Civil de Concórdia - Santa Catarina entendeu que a consumidora cometera abuso de direito, e concedeu tutela antecipada à fabricante conforme explica na decisão: "tendo em vista que as fotos, vídeos e sítios que estão veiculados na rede mundial de computadores, poderá atingir diretamente uma gama de consumidores, prejudicando, paulatinamente, a imagem da autora". ${ }^{47}$

O caso acabou em acordo ${ }^{48}$, mas deixou claro o poder das ferramentas hoje à disposição dos usuários no ambiente da web 2.0. Ambiente no qual a tecnologia parece não parar de evoluir, onde já se fala na terceira onda: a web semântica ou web 3.0 que dará mais sentido aos já consagrados mecanismos de busca. ${ }^{49}$

Neste ambiente de intensa ampliação de atividades nas redes sociais, as relações humanas se tornam mais complexas e por conseguinte geram questões jurídicas também complexas. Como reflexo natural é notável na imprensa a frequência com que temas como liberdade de expressão e censura, intimidade e exposição pública, segurança e privacidade, acesso

$47 \quad$ http://www.conjur.com.br/2011-mar-15/juiz-determina-site-protesto-renault-seja-retirado-ar. Acesso em 2/4/2011.

${ }^{48}$ http://esaj.tjsc.jus.br/cpo/pg/show.do;jsessionid=8425BD50391B2E9FB7CD03B85F730F09.nod e2? processo. foro $=19 \&$ processo. codigo $=0 \mathrm{~J} 0002 \mathrm{CZN} 0000 \& \mathrm{cdForo}=19 \& \mathrm{cdComarca}=-1$. Acesso em $7 / 4 / 2011$ 
restrito e livre acesso vem sendo associados ao fenômeno do crescimento das redes sociais.

\subsection{Problemas jurídicos das redes sociais.}

O desenvolvimento e o uso das tecnologias relacionadas a web 2.0, e mais especificamente a crescente adoção das redes sociais parece reabrir a discussão sobre a proteção dos direitos personalíssimos constitucionalmente consagrados, como observa Caitlin Mulholland:

"De fato, a natureza "imaterial" da rede de computadores desencadeou questionamento em relação à tutela da privacidade, sigilo, segredo e intimidade dos consumidores que se relacionam através da rede, valores estes protegidos pela Constituição Federal e ameaçados por este novo meio comunicacional". 50

A proteção da honra, sigilo, intimidade e imagem ganham novos contornos quando as fronteiras entre público e privado ficam menos evidentes no ambiente online. Os direitos da personalidade e o consequente estabelecimento do sistema de responsabilidade civil na Internet estão no centro dos problemas jurídicos relacionados às redes sociais.

Uma matéria jornalística exibida no programa Fantástico, em 2010, trouxe para a televisão o que centenas de milhares de pessoas já tinham visto no YouTube: uma briga envolvendo duas amigas e o marido de uma delas $^{51}$. O motivo não poderia ser mais íntimo: a infidelidade conjugal.

A partir deste único exemplo é possível notar como o Art. $5^{\circ}, \mathrm{X}$ do

\footnotetext{
${ }^{50}$ Caitlin Mulholland, Internet e Contratação: Panorama das relações contratuais eletrônicas de consumo, Ed Renovar, 2006, p. 52.

$51 \mathrm{httn} / /$ fantastico oloho com/Inrnalismo/FANT/0 MIJI.1605857-1560500 htm1 Acesso em
} 
texto constitucional ${ }^{52}$ é posto à prova. Neste sentido assinala Guilherme Magalhães Martins:

"O desenvolvimento tecnológico traz consigo novos riscos à segurança dos consumidores, incluisve sob o ponto de vista do direito fundamental à privacidade (art. $5^{\circ}, \mathrm{X}$, Constituição da República), a partir do acesso às informações sobre o indivíduo e do uso que se faz delas". ${ }^{53}$

É no mínimo difícil garantir o direito à intimidade, vida privada, honra e imagem das pessoas envolvidas no episódio acima relatado, se a qualquer momento, qualquer um com acesso a um computador conectado à Internet pode ver e rever cenas que não guardam nenhuma obediência à proteção dos direitos da personalidade.

No entanto, pode-se afirmar que as noções de público e privado assumem novam acepções na medida em que a comunicação mediada pelo computador evolui. Slove ${ }^{54}$ apresenta duas afirmativas que contribuem para reformular o conceito de privacidade no mundo digital:

(I) a privacidade no atual estágio de desenvolvimento e uso das redes sociais não tem o sigilo como requisito, e

(II) o fato de certa informação ter sido revelada não significa que ela perde automaticamente seu caráter privado.

Afirma também que as gerações mais novas enxergam a privacidade de forma mais flexível, pois dentro do contexto das redes sociais as informações são rotineiramente reveladas e compartilhadas. Cabe ressaltar no entanto que há um limite para tamanha flexibilização, e este limite segundo Guilherme Magalhães Martins é colocado pela dignidade da

\footnotetext{
${ }^{52}$ Art. $5^{\circ}, \mathrm{X}, \mathrm{CF}$ - são invioláveis a intimidade, a vida privada, a honra e a imagem das pessoas, assegurado o direito a indenização pelo dano material ou moral decorrente de sua violação;

${ }^{53}$ Martins, Guilherme Magalhães. Responsabilidade Civil por Acidente de Consumo na Internet. São Pauln · Fditora dos Trihunais 7008 n 57
} 
pessoa humana e pelo respeito à personalidade de cada um. ${ }^{55}$

Segundo Jonathan Zittrain não é só a noção de público e privado que muda com a Internet, mas também o que é considerado "notícia" e que será consequentemente exposto na imprensa. Hoje para qualquer fato que aconteça, há qualquer momento, há "3 braços segurando um telefone celular com câmera acoplada gravando o evento pronto para, se necessário, ser veiculado no noticiário noturno". ${ }^{56}$

Caso a pauta não seja considerada relevante o suficiente para as mídias tradicionais, o caminho das redes sociais tem sido adotado. Muitas vezes depois de atingir um certo nível de audiência na Internet, o caso antes descartado, pode ganhar destaque na imprensa de massa tendo o sucesso no ambiente digital como gancho, a exemplo do que aconteceu com a situação da briga entre duas mulheres anteriormente mencionada.

Além dos problemas relacionados à criação e disseminação de conteúdo ofensivo por meio das redes sociais que atacam diretamente o direito à honra, à imagem, e à vida íntima, há os impactos que a exposição na Internet traz para a segurança e privacidade dos usuários. Tais questões também vem ocupando grande parte do noticiário sobre tecnologia e legislação. ${ }^{57}$

Boyd e Ellison ${ }^{58}$ apontam para uma certa incoerência entre o desejo dos usuários de redes sociais de protegerem suas informações, e aquilo que colocam em seus perfis. Para Gross e Acquisti os resultados de uma das

\footnotetext{
${ }^{55}$ Martins, Guilherme Magalhães. Responsabilidade Civil por Acidente de Consumo na Internet. São Paulo: Editora dos Tribunais, 2008. p. 56.

${ }^{56}$ Tradução livre para: About the fact that anytime anything of any note happens, there are three arms holding cell phones with cameras in them or video records capturing the event ready to go on the nightly news, if necessary. http://bigthink.com/ideas/16108. Acesso em 12/04/2011.

57 http://g1.globo.com/tecnologia/noticia/2011/04/conheca-os-principais-problemas-de-segurancado-facehonk html Acesso em 2.9/04/7.011
} 
primeiras pesquisas acadêmicas sobre privacidade nas redes sociais mostraram que o perigo percebido de expor dados pessoais no Facebook era menor do que as vantagens da exposição. ${ }^{59}$ A mesma pesquisa mostrou que a partir de dados fornecidos nos sites era possível a reconstrução de informações bancárias e de números de identidade, usados posteriormente para prática de crimes virtuais.

Dando sequencia a tendência de exposição da vida privada por meio Internet, começa a fazer sucesso no Brasil uma rede social na qual o usuário diz onde está, toma conhecimento sobre onde outras pessoas estão, e faz comentários sobre sua localização. Trata-se do Foursquare. ${ }^{60}$

Com tantos detalhes da vida cotidiana dos usuários expostos ao público, o que acontece quando uma pessoa mal intencionada usa estas informações para a prática de crime? Hoje crimes virtuais, ou aqueles relacionados aos direitos personalíssimos, mas quem poderia prever os usos que poderiam ser empregados sobre tamanha quantidade de dados exposta?

O problema que se coloca não se restringe apenas ao Foursquare, mas também ao Facebook, ao Orkut, ao Twitter e a qualquer outro site de rede social no qual informações aparentemente inocentes sobre a rotina de cada um são postas na vitrine.

O debate ganha ainda mais relevância quando crianças e adolescentes são ora autores ora vítimas das constantes violações aos direitos da personalidade. Dois pontos merecem especial atenção: o primeiro, por óbvio, diz respeito à tutela deste grupo hipossuficiente por natureza. Por diversos países há demonstrações de preocupação com a

\footnotetext{
${ }^{59}$ Gross, R.; Acquisti, A. (2005). Information Revelation and Privacy in Online Social Networks. AC.M Workshon on Privacv in the Flectronic Societv (WPFS) $2005 \mathrm{n} 8$
} 
segurança das crianças e adolescentes no ambiente de Internet, a exemplo do "dia mundial da Internet segura" que em 2011 teve como lema: "Estar online é mais que um jogo, é a sua vida". 61

O segundo ponto trata da responsabilidade dos pais pelos atos dos filhos menores, conforme preceitua o inciso I do artigo 932 do Código Civil:

Art. 932. São também responsáveis pela reparação civil:

I - os pais, pelos filhos menores que estiverem sob sua autoridade e em sua companhia;

Segundo Cavalieri esta é uma das modalidades de responsabilidade por fato de outrem, e que se relaciona diretamente com as obrigações decorrentes do poder familiar, entre elas, o dever de assistência moral e material, de cuidado e de vigilância. ${ }^{62}$

Em 2008 o Tribunal de Justiça de Rondônia condenou os pais de 19 jovens a indenizarem um professor vítima de ofensas por meio de comunidade do Orkut, conforme aduz a ementa:

"Indenizatória. Danos morais. Comunidade virtual. Divulgação, por menores, de mensagens depreciativas em relação a professor. Identificação. Linguagem chula e de baixo calão. Ameaças. Ilícito configurado. Ato infracional apurado. Cumprimento de medida sócio-educativa. Responsabilidade dos pais. Negligência ao dever legal de vigilância". 63

Em decisão semelhante o TJ do Rio Grande do Sul também condenou ao pagamento de indenização por danos morais a mãe de um adolescente de 14 anos por cyberbullying ${ }^{64}$ contra um um colega de escola. Montagens com fotos da vítima e mensagens de conteúdo difamatório

61 http://www.direitosdacrianca.org.br/midiateca/videos/campanha-dia-mundial-da-Internetsegura-2011. Acesso em 10/04/2011.

${ }_{63}^{62}$ Cavalieri Filho, Sergio: Programa de Responsabilidade Civil. Ed Atlas, 2007, p. 20.

$63 \mathrm{http}: / / \mathrm{www} . j u s b r a s i 1 . c o m . b r / n o t i c i a s / 111882 /$ pais-sao-condenados-por-ofensas-dos-filhos-noorkut. Acesso em 03/03/2011.

${ }^{64} \mathrm{O}$ Cyberbullying é uma prática que remete a hostilização do próximo por meio de tecnologias da informacão F.nvolve o fortalecimento de comnortamentos nocivos maldosos e renetidos contra 
foram mantidas em uma página de um site de rede social. ${ }^{65}$

É de especial interesse para o presente trabalho a análise das hipóteses de reponsabilidade por fato de terceiro, pois os provedores de serviços de Internet detentores de sites de redes de relacionamento vem recebendo tratamento semelhante em litígios nos quais não é possível localizar o autor do dano. O Google por exemplo tem aproximadamente 1,5 mil ações judiciais no Brasil, sendo a maioria por conteúdo postado no Orkut. Em metade dos julgados o judiciário responsabiliza o Google pelo material ilícito ali encontrado. ${ }^{66}$

A questão jurídica que permeia todos os exemplos relatados no presente trabalho se refere ao sistema de responsabilidade civil nas redes sociais. A regra geral contida no artigo 927, CC estabelece como consequência do ato ilícito o dever de indenizar:

Art. 927. Aquele que, por ato ilícito (arts. 186 e 187), causar dano a outrem, fica obrigado a repará-lo.

Parágrafo único. Haverá obrigação de reparar o dano, independentemente de culpa, nos casos especificados em lei, ou quando a atividade normalmente desenvolvida pelo autor do dano implicar, por sua natureza, risco para os direitos de outrem.

Portanto para cada perfil falso criado em uma rede social, comunidade ofensiva à imagem de uma pessoa, ou conteúdo ilegal postado em um site de compartilhamento de vídeos, entre outros exemplos, tem-se uma vítima, um autor, e o consequente dever de indenizar. Porém quando estes atos ilícitos são cometidos em ambiente de Internet e mais especificamente em sites de rede social, a identificação do ofensor pode não ser possível dificultando a reparação do dano.

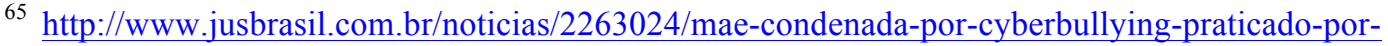
filho-adolescente. Acesso em 03/03/2011.

$66 \mathrm{httn} / / \mathrm{www}$ iushrasil com hr/noticias/7.794006/nrohlemas-com-iustica-nodem-fechar-orkut-no- 
A jurisprudência que será explorada mais adiante trata desta situação na qual aquele que é diretamente responsável pelo dano não é passível de ser identificado. Restando muitas vezes ao provedor de serviços de Internet responder por fato de terceiro. $\mathrm{O}$ ordenamento jurídico brasileiro divide a responsabilidade civil da seguinte forma: ${ }^{67}$

(I) Responsabilidade subjetiva: fundada na culpa, onde se faz necessária a comprovação de culpa do agente conforme artigo $186, \mathrm{CC}^{68} \mathrm{e}$ 927, CC.

(II)Responsabilidade objetiva: sem persecução da culpa e fundada na teoria do risco.

O foco da responsabilidade civil objetiva está em garantir que a vítima seja reparada pelo dano sofrido, pois:

"Com o intuito de não deixar desamparada a vítima, desenvolvera, paulatinamente o novo sistema de responsabilização com base na teoria do risco, segundo a qual quem exerce determinadas atividades deve ser responsável também pelos seus riscos, independentemente de quaisquer considerações em torno de seu comportamento pessoal. A essa nova espécie de responsabilidade, fundada no risco, convencinou-se chamar responsabilidade objetiva, porque desvinculada da valoração da conduta do sujeito". ${ }^{69}$

Em consonância com a proposta de garantir a mais ampla possibilidade de ressarcimento à vítima, encontra-se a previsão de responsabilidade civil por fato de terceiro. É a exceção da regra que afirma só responder pelo fato quem lhe dá causa, conforme assinala Cavalieri:

"A regra em sede de responsabilidade civil é que ada um responda por seus próprio atos, exclusivamente pelo que fez...É o que tem sido chamado de responsabilidade por fato próprio, cuja justificativa está no próprio princípio informador da teoria da reparação. Excepcionalmente, nas hipóteses previstas no art 932 do Código Civil uma pessoa pode vir a responder pelo fato de outrem.

\footnotetext{
${ }^{67}$ Cavalieri Filho, Sergio: Programa de Responsabilidade Civil. Ed Atlas, 2007, p. 20.

${ }^{68}$ Art. 186, CC: Aquele que, por ação ou omissão voluntária, negligência ou imprudência, violar direito e causar dano a outrem, ainda que exclusivamente moral, comete ato ilícito.

${ }^{69}$ Tenedino Gustavo: Rarhnza Heloisa Helena: Rodin de Moraes Maria Celina Códion Civil
} 
Teremos, então, a responsabilidade indireta, ou responsabilidade pelo fato de outrem". ${ }^{70}$

No entanto, faz-se necessária a observação no sentido de que os provedores de serviços de Internet, modalidade na qual se inclui as redes sociais não são contempladas pelos incisos do artigo 932, CC conforme descrito acima. Resta portanto mais duas hipóteses para a aplicação da responsabilidade objetiva por fato de terceiro às redes sociais. A primeira diz respeito a definição do serviço em tela como atividade de risco. A segunda classifica como relação de consumo aquela estabelecida entre os sites de redes sociais e seus usuários.

O paragrafo único do artigo 927, CC traz a segunda cláusula geral de responsabilidade objetiva, da qual aduz-se que responde objetivamente por danos causados aquele que desenvolve atividade de risco. Porém, o Código Civil não define o que significa atividade que representa riscos para o direito alheio, deixando esta tarefa a cargo da jurisprudência, conforme assinalam Gustavo Tepedino et all:

\footnotetext{
“A inovação dá ao Poder Judiciário ampla discricionariedade na avaliação das hipóteses de incidência da responsabilidade sem culpa. Ao contrário de outras normas que preveem a responsabilidade objetiva, a redação desta cláusula geral, por sua amplitude, não se mostra precisa, uma vez que toda e qualquer atividade implica, por sua natureza, "riscos para os direitos de outrem". 71
}

Esta flexibilidade de interpretação quanto ao enquadramento das atividades de risco vem produzindo decisões que classificam a atividade de manter um site de rede social como atividade de risco, como se observa em recente acórdão do TJMG ao julgar ação indenizatória ajuizada por usuário vítima de ofensas no Orkut:

"O prestador do serviço de site de relacionamento, que disponibiliza na Internet um serviço sem dispositivos de segurança e controle mínimos e, ainda, permite a publicação de material de conteúdo livre, sem sequer identificar o usuário, deve

\footnotetext{
${ }^{70}$ Cavalieri Filho Seroin: On Cit n 177
} 
responsabilizar-se pelo risco oriundo do seu empreendimento e de forma objetiva por incidência do CDC". ${ }^{72}$

O acórdão supracitado além de trazer a teoria do risco para justificar a aplicação do parágrafo único do artigo 927 do Código Civil, também aponta a incidência do Código de Defesa do Consumidor para ratificar a condenação do provedor de serviços de Internet à indenização da vítima.

Para parte da jurisprudência a relação entre usuário e sites de redes sociais é de consumo, o que justifica a aplicação do art. 14 e $\S 1^{\circ}$ do referido diploma e a consequente incidência da responsabilidade objetiva conforme explicita o dispositivo:

Art. 14. O fornecedor de serviços responde, independentemente da existência de culpa, pela reparação dos danos causados aos consumidores por defeitos relativos à prestação dos serviços, bem como por informações insuficientes ou inadequadas sobre sua fruição e riscos.

A aplicação do CDC se dá por meio do argumento de que apesar da gratuidade do serviço prestado pelos sites de redes sociais, o fornecedor do serviço aufere benefícios indiretos, a exemplo dos ganhos obtidos com publicidade. $^{73}$ É neste mesmo sentido de ganhos indiretos que Claudia Lima Marques afirma a incidência do CDC aos sites de leilão virtual:

"Interessa-nos aqui o fato de os "leilões" pela Internet serem ipso facto uma atividade comercial, dada a remuneração direta (...) ou indireta (por publicidade, por convênio com provedores ou por impulsos telefônicos) do organizador do leilão" ${ }^{74}$ (grifo da autora)

A indenifição quanto a norma aplicada ao sites de redes sociais nos casos de responsabilidade civil reflete o natural descompasso entre o avanço tecnológico e a lei. As diversas possibilidades de comunicação

\footnotetext{
${ }^{72}$ TJMG, Ap. 1.0024.07.794839-6; rel. Des. Márcia de Paoli Balbino; j. em 02/12/2010. http://www.jusbrasil.com.br/noticias/2298621/tj-de-rondonia-aplica-codigo-de-defesa-doconsumidor-contra-o-google-para-responsabiliza-lo-por-perfil-falso. Acesso em 03/03/2011.

${ }^{74}$ Marnues Claudia I ima Confianca no comércio eletrônico e a nrotecão do consumidor São
} 
criadas pela Internet e especialmente colocadas em prática no ambiente colaborativo da web 2.0, aumentam os casos de responsabilidade civil tanto em número quanto em diversidade. Neste sentido, Guilherme Maritns Magalhães observa:

"Os conceitos e as categorias tradicionais de responsabilidade civil não foram idealizados para um ambiente aberto, caracterizado pela participação de múltiplos sujeitos e organizações frequentemente amparados pelo anonimato, perfazendose a comunicação por meio de protocolos". ${ }^{75}$

Os sites de redes sociais se inserem nesta realidade de comunicação na qual há uma multiplicidade de sujeitos e comunidades virtuais, que travam relações fundadas na maior liberdade de expressão e menor privacidade que o ambiente permite. Um caminho apontado pela doutrina com o obejtivo de esclarecer o papel dos fornecedores do ambiente de Internet é a definição das atividades desempenhadas pelos principais tipos de provedores de serviços de Internet, e a consequente natureza de responsabilidade civil envolvida.

\subsection{Responsabilidade do provedor de serviços de Internet por ato de terceiro: um breve resumo dos caminhos apontados pela doutrina.}

Um provedor de serviços de Internet desempenha usualmente pelo menos uma das seguintes atividades:

(a) provedor de backbone: oferece conectividade, vende sua infraestrutura a outras empresas que prestarão outros serviços na Internet. É um transmissor de informação.

(b) provedor de acesso: disponibiliza o acesso à Internet a seus usuários por meio de um endereço IP.

(c) provedor de hospedagem: cede espaço em seu servidor para que seus usuários armazem informação. 
(d) provedor de conteúdo: pode tanto criar e disponibilizar a informação, quanto apenas disponibilizar informação gerada por terceiro; e

(e) provedor de correio eletrônico: possibilita o envio e recebimento de mensagens disponibilizando nome e senha ao usuário.

Para cada atividade acima mencionada a doutrina indica o tipo de responsabilidade em caso de atos ilícitos cometidos por terceiro.

O provedor de backbone não guarda relação direta com o usuário final, pois seu cliente é o provedor de acesso ou de hospedagem. Portanto configura uma atividade isenta de responsabilidade quanto a possíveis ilícitos cometidos por terceiros.

O provedor de acesso que se limita a fornecer a conexão à Internet a seus usuários também não pode ser responsabilizado pelo conteúdo das informações produzidas, enviadas ou postadas por usuários finais. É recorrente na doutrina a analogia dos provedores de acesso com as empresas telefônicas.

Marcel Leonardi adota a teoria intermediária para os provedores de acesso, a saber: só podem ser responsabilizados por ato de terceiro caso sejam notificados sobre certo conteúdo ilegal e nada façam para cessar o dano $^{76}$. Confere portanto responsabilidade subjetiva àquela do provedor de acesso que se omite ou é negligente diante da ilicitude praticada por usuários finais do seu serviço:

"Isto ocorrerá quando o provedor de acesso deixar de interromper a prestação dos serviços a um usuário que insista em praticar atos ilícitos utilizando-se da conexão oferecida pelo provedor, desde que este tenha sido previamente informado a esse respeito e desde que não haja dúvidas sobre a ilicitude da conduta perpetrada pelo usuário". ${ }^{77}$

${ }^{76}$ I ennardi Marcel On Cit n 98 
Quanto ao provedor de correio eletrônico é dominante a posição de que não responde nem pelo conteúdo das mensagens, nem pelo envio não solicitado. Guilherme Martins Magalhães observa neste sentido:

“...responsabilizar o provedor pelo recebimento de mensagens indesejadas - a menos que haja obrigação contratual nesse sentido - não é a melhor solução, não se lhe podendo imputar um dever de triagem de todas as mensagens recebidas, o que possivelmente levaria a um maior rigor na aplicação de filtros, aumentando a possibilidade de serem também bloqueadas mensagens lícitas e causando, pela via transversa, novos danos ao consumidor". ${ }^{78}$

De interesse especial para o presente trabalho a situação dos provedores de hospedagem, dos quais fazem parte sites de redes sociais e de compartilhamento de fotos e vídeos. ${ }^{79}$ De acordo com diversos autores ${ }^{80}$ citados por Leonardi ${ }^{81}$ o provedor de hospedagem não é responsável pelo conteúdo dos sites que hospeda em seus servidores.

Leonardi ${ }^{82}$ destaca que a responsabilidade do provedor de hospedagem surge a partir do momento em que este passa a ter conhecimento inequívoco da existência de conteúdo ilícito em seus servidores.

Por fim, os provedores de conteúdo serão responsabilizados pelas informações produzidas por terceiros no caso de exercerem controle editorial prévio. No entanto, há que se diferenciar a informação é que previamente analisada e posteriormente publicada, daquela que não passa pelo crivo do provedor de conteúdo. É neste sentido que observa Guilherme Magalhães Martins: "quanto maior for a discricionariedade de decidir o que será publicado ou transmitido, mas evidente será a responsabilidade

\footnotetext{
${ }^{78}$ Martins, Guilherme Magalhães. Responsabilidade Civil por Acidente de Consumo na Internet. São Paulo: Editora dos Tribunais, 2008. p. 221.

${ }^{79}$ Idem. P. 284.

${ }^{80}$ Autores: Ricardo Luis Lorenzetti, Gustava Testa Corrêa, Sônia Aguiar do Amaral, Erica Brandini Barbagallo, e Waldo Augusto Roberto Sobrino.

${ }^{81}$ I ennardi Marcel On Cit $\mathrm{n} 105$
} 
decorrente de tal decisão". ${ }^{83}$

Mais uma vez a ressalva de conhecimento inequívoco por parte do provedor de serviços é apresentada como justificativa da possível responsabilização por ato de terceiro.

Para Leonardi antes de determinar a responsabilidade do provedor de serviços por ato de outrem, é preciso verificar se o provedor cumpriu com seus deveres intrínsecos:

"Feita esta análise, e concluindo-se que o provedor de serviços tenha, de fato, cumprido com seus deveres, resta saber se ele deve ser considerado um mero transmissor, distribuidor ou editor do conteúdo, bem como se deixou de impedir ou fazer cessar tal prática, quando lhe competia tal providência ou, ainda, se aufere vantagem econômica direta em razão do ato ilícito praticado por terceiros". ${ }^{84}$

Os deveres mencionados por Leonardi são: utilizar tecnologias apropriadas, conhecer os dados de seus usuários, manter informações por tempo determinado, manter em sigilo os dados dos usuários, não monitorar, não censurar e informar em face de ato ilícito cometido por usuário.

Ressalta-se porém que a busca pela violação de um "dever jurídico originário" como forma de caracterizar o dever "sucessivo" de indenizar, não está em consonância com o conceito de responsabilidade objetiva, conforme observa a doutrina mais atual. ${ }^{85}$

Já a separação das atividades desempenhadas, apesar da interrelação entre elas, é fundamental para que se identifique o tipo de responsabilidade envolvida em cada modalidade de prestação de serviço. Guilherme Magalhães Martins lembra que a Diretiva 2000/31, artigos 12, 13 e 14 trata

\footnotetext{
${ }^{83}$ Martins, Guilherme Magalhães. Op. Cit., p. 296.

${ }^{84}$ Leonardi, Marcel. Op. Cit. p. 95.

${ }^{85}$ Tenedino Gustavn: Rarhoza Helnisa Helena: Rodin de Moraes Maria Celina Códion Civil
} 
a responsabilidade dos provedores segundo a atividade de cada um deles. ${ }^{86}$

\subsection{A experiência internacional em casos de responsabilidade civil em redes sociais.}

A análise da legislação estrangeira relacionada à responsabilidade civil dos provedores de Internet é de especial relevância para o atual cenário brasileiro no qual se aguarda a aprovação do anteprojeto de lei que trata do marco regulatório da Internet no pais.

Nos Estados Unidos as normas de regulamentação são encontradas em dois documentos: Communications Decency Act de 1996 e Digital Millennium Copyright Act, de 1998. Para os países da Comunidade Européia as principais regras estão nas chamadas Diretivas 2000/31/CE e 2001/29/CE.

Importa lembrar que durante um tempo se cogitou a não regulamentação da itnernet, tendo John Perry Barlow e sua "Declaração de Independência do Ciberespaço" ${ }^{" 87}$ como ícone deste pensamento. Para John Palfrey, Co-Diretor do Centro de Pesquisa Berkman sobre Internet e Socidade, Barlow representa a primeira de quatro fases pelas quais passou o processo de regulamentação da Internet nos Estados Unidos. São elas: (I) Internet aberta, do surgimento da rede até o ano 2000; (II) acesso negado, de 2000 até 2005; (III) acesso controlado, de 2005 até 2010; e (IV) acesso contestado, a fase atual. ${ }^{88}$

\footnotetext{
${ }^{86}$ Martins, Guilherme Magalhães. Responsabilidade Civil por Acidente de Consumo na Internet. São Paulo: Editora dos Tribunais, 2008. P. 281.

${ }^{87} \mathrm{https}$ ://projects.eff.org/ barlow/Declaration-Final.html. Acesso em 29/04/2011.

88 Inhn Palfrev. Four Phases of Internet Reoulation httn //ssrn com/ahstract=1658191
} 
A relevância da regulamentação é apontada por Palfrey pelo fato das tecnologias de Internet serem neutras e tanto servirem para o bem quanto para o mal. Aponta para a necessidade de manter o ambiente de Internet seguro para crianças e adolescentes quando se trata de pedofilia, pornografia e cyberbullying por exemplo. $O$ discurso da não regulamentação dizia respeito a um ambiente a parte da realidade, no qual seria praticamente impossível estabelecer algum tipo de norma.

A fase do "acesso negado" para Palfrey tem em países como a China e Arábia Saudita os símbolos máximos de tentativas de bloquear o acesso da população a certos tipos de conteúdo. Chama a atenção para as atividades de filtragem e os mapas de bloqueio de Internet ao redor do mundo, devidamente documentadas por iniciativas como a OpenNet. ${ }^{89}$ No Brasil vale lembrar do já citado caso do bloqueio do YouTube por ocasião do evento envolvendo a modelo Daniela Cicarelli.

A terceira fase de regulamentação da Internet citada por Palfrey, "acesso controlado" diz respeito às tentativas por parte dos estados em efetivamente controlar a vida online do cidadão. É a fase na qual a regulamentação é enfatizada, os mecanismos de filtragem são mais sofisticados, e as exigências de indentificação, registros e licenças são intensificadas. Cita como exemplo o processo para usar um cybercafé na Turquia que requer prova de indentidade, login na frente do responsável pelo estabelecimento para realizar o identificação da máquina, seu IP, bem como registrar o exato período de tempo de uso da Internet.

Como a Internet deve ser regulada e como o conjunto de normas pode ter aplicação mais efetiva é a chave para a quarta fase, "acesso contestado". Para Palfrey o momento atual é significativo pois começa a haver um debate em diversos países, envolvendo usuários, empresas e 
governo sobre a regulamentação da Internet, na qual os provedores de serviços exercem papel significativo.

Guilherme Magalhães Martins considera a experiência verificada na jurisprudência americana sobre a responsabilidade civil dos provedores uma forte referência a ser estudada por outros sistemas. ${ }^{90}$ São três possíveis categorias de enquadramento de responsabilidade, a saber:

(I) Direct liability (responsabilidade direta): o provedor pratica o ato ilícito.

(II) Contributory liability (responsabilidade compartilhada): o provedor não pratica o ato, mas de alguma maneira contribui para sua ocorrência, ou tem conhecimento da ilegalidade e se mantem inerte.

(III) Vicarious liability (responsabilidade indireta): surge do efetivo controle da atividade por parte do provedor, ou da auferição de vantagem econômica com a referida atividade.

As categorias II e III acima mencionadas aumentam a gama dos possíveis responsáveis, ao mesmo tempo em que não limitam a verificação do nexo de causalidade entre autor e vítima como ocorre na responsablização direta.

Num primeiro momento a jurisprudência norte americana pendeu para a responsabilidade compartilhada, posteriormente ao adotar a efetiva diferenciação entre o provedor de acesso puro e o provedor de serviços, surgiu o primeiro caso de afastamento de responsabilidade do provedores. ${ }^{91}$

Em termos de regulamentação, tanto na Comunidade Européia

\footnotetext{
${ }^{90}$ Martins Magalhães Guilherme On Cit n 2.90
} 
quanto nos Estados Unidos, são verificadas significativas semelhanças quanto as limitações da responsabilidade dos provedores de serviços de Internet. Para Leonardi um ponto positivo presente nos dois sistemas é a análise por atividade desempenhada e não por classe de provedor, pois é comum que empresas do setor disponibilizem vários serviços aos usuários. As limitações de responsabilidade se aplicam a cada atividade e não ao serviço como um todo. ${ }^{92}$

As atividades de mera transmissão e de fornecimento de acesso são normalmente isentas de responsabilidade nos dois sistemas, bem como aquelas classificadas como caching (o armazenamento temporário em um servidor local, agilizando o tráfego dos dados). Portanto, são beneficiados por esta medida os provedores de backbone, de acesso, de correio eletrônico e de hospedagem.

Também para o provedor de conteúdo que não cria ou modifica a informação que disponibiliza há isenção de responsabilidade. As normas em tela partem do princípio de serem tais provedores de conteúdo meros intermediários, conforme a primeira parte do artigo 12 da Diretiva 2000/31/CE e a seção 230, a, 1 do Communications Decency Act.

Art. 12o , Diretiva 2000/31/CE - Simples transporte:

1. No caso de prestações de um serviço da sociedade da informação que consista na transmissão, através de uma rede de comunicações, de informações prestadas pelo destinatário do serviço ou em facultar o acesso a uma rede de comunicações, os Estados-Membros velarão por que a responsabilidade do prestador não possa ser invocada no que respeita às informações transmitidas, desde que o prestador: a) Não esteja na origem da transmissão; b) Não seleccione o destinatário da transmissão; e c) Não seleccione nem modifique as informações que são objecto da transmissão.

Seção 230, alínea c, número 1 do Communications Decency Act: 
“nenhum provedor ou usuário de um 'serviço informático interativo' será considerado como o editor ou autor de uma informação fornecida por outro provedor de conteúdo".

Leonardi afirma ser exagerada a proteção dada pela lei americana aos provedores de serviços considerados intermediários, pois são sempre isentos de responsabilidade por ato de terceiro mesmo quando cientes dos eventos.

"Como demonstrado, o Congresso norte-americano rendeu-se à poderosa pressão dos provedores de serviços de Internet e os eximiu de qualquer responsabilidade pelo conteúdo que armazenam, transmitem ou divulgam, de forma que a reparação de eventuais danos causados à honra de terceiros por conteúdo ofensivo somente pode ser pleiteada do autor da informação lesiva." ${ }^{, 93}$

No que tange a proteção de direitos de propriedade intelectual e os provedores de serviços de Internet, a legislação americana se apresenta mais desenvolvida e detalhada do que o sistema europeu. Trata-se do Digital Millennium Copyright Act (DMCA) que objetivou estabelecer um equilíbrio entre a segurança da propriedade intelectual e a manutenção da atividade dos provedores de Internet, sem que estes se mantivessem no centro dos litígios envolvendo responsabilidade por ilegalidades cometidas por terceiros.

De acordo com DMCA os provedores quando desempenham atividades de mera intermediação são considerados isentos desde que atendam a requisitos especificados na lei. Portanto provedores de backbone e de acesso são contemplados pela não responsabilização.

As questões relativas ao armazenamento temporário de informações (caching) foram tratadas com maior riqueza de detalhes pelo DMCA em relação a Diretiva 2000/31/CE, impondo aos provedores de serviços a observância de certos aspectos para que se beneficiem da insenção de 
responsabilidade por ato de terceiro. São os requisitos segundo Leonardi:

“a) o material for disponibilizado na rede por um indivíduo que não seja o próprio provedor;

b) for transmitido por este através do sistema ou da rede para terceiros; e

c) o armazenamento for realizado através de processo automatizado com o propósito de tornar disponível o material aos usuários do sistema ou rede que porventura o requisitem". ${ }^{94}$

Especificamente sobre o provedor de hospedagem tanto o DMCA quanto a Diretiva 2000/31/CE estabelecem como regra a imunidade, desde que não conheça o conteúdo armazenado em seu servidor, bem como não tenha acesso a informações que de alguma forma deixem claro a ilegalidade. Nos dois sistemas exige-se a retirada ou bloqueio do conteúdo tão logo o provedor tome conhecimento do conteúdo.

No que se refere aos provedores de hospedagem, o detentor de direitos de propriedade intelectual tem a possibilidade de notificar a empresa de hospedagem para que efetue o bloqueio conteúdo ilegal encontrado em seus servidores. É chamado de "notice and take down". Para Leonardi, um benefício significativo conforme assinala:

"A principal vantagem do sistema de notice and take down é permitir aos provedores de serviços tomar conhecimento da existência de material ilegal em seus servidores e removê-lo sem a necessidade de medidas judiciais específicas com os mesmos propósitos". 95

Sobre este tema é interessante notar a experiência do site chillingeffects.com que trata de informar sobre as iniciativas relacionadas ao sistema de notice \& take down acima mencionado, com objetivo de esclarecer direitos e deveres de quem participa de alguma forma do ambiente online.

Cabe ressaltar que o DMCA, ao contrário da Diretiva 2000/31/CE,

\footnotetext{
${ }^{94}$ I ennardi Marcel On cit n 37
} 
estabelece com clareza o que significa "grau de conhecimento necessário" para o bloqueio ou retirada de conteúdo de alegada ilicitude. Tais requisitos devem constar da notificação e estão elencados na seção (B) do DMCA, a saber: 96

(I) vedação ao anonimato: estar assinada por representante do detentor dos direitos de propriedade intelectual violados;

(II) identificação do material protegido bem como do material apontado como ilegal encontrado nos servidores;

(III) informações claras para que o provedor localize o material apontado como ilegal;

(IV) informações para contato com o notificante;

(V) declaração do notificante sobre o uso não autorizado do detentor dos direitos de propriedade intelectual;

(VI) declaração do notificante sobre a idoneidade das informações prestadas e autorização para agir em nome do detentor dos direitos de propriedade intelectual.

Ainda sobre o sistema de Notice and Take Down, o DMCA estebelece que o provedor não responde ao retirar ou bloquear conteúdo apontado com ilegal e que posteriormente vier a ser provado legal. Estabelece também a responsabilização por danos causados ao provedor de hospedagem, de conteúdo e ao detentor de direitos de propriedade intelectual o terceiro que age com má fé e promove a notificação de conteúdo lícito. ${ }^{97} \mathrm{~A}$ este respeito também se observa lacuna na regulamentação presente na Diretiva 2000/31/CE.

Por fim, o DMCA estabelece duas condições, sem equivalente na lesgislação da CEE, para que os provedores de serviços de Internet se

\footnotetext{
${ }^{96}$ T ennardi Marcel On cit n 38
} 
beneficiem das isenções postas pela referida lei: o provedor se obriga a adotar política que interrompa serviços os usuários reincidentes; deve facilitar as medidas técnicas utilizadas pelos detentores de direitos de propriedade intelectual com fins de identificação e proteção de conteúdo próprio.

Sobre a possibilidade de ordem judicial para bloqueio a informações ilegais, apesar do recurso existir, Leonardi explicita que cabe ao julgador analisar os impactos de tal situação para o provedor, para o detentor dos direitos violados, bem como a viabilidade técnica em realizar o referido bloqueio sem interferência para as informações legítimas que figuram na mesma rede. ${ }^{98}$ Lembra ainda que a ordem judicial só pode ser emitida caso o provedor já tenha sido notificado e tido a oportunidade de se manifestar.

Tanto a Diretiva 2000/31/CE no seu artigo 15 quanto o DMCA na seção B não impõe aos provedores de maneira geral um dever de monitoramento. Nem mesmo os provedores de hospedagem estão obrigados a de forma espontânea supervisionar o conteúdo das páginas que hospedam. Porém, como observa Martins, estão obrigados a responderem demandas judiciais no sentido de vigilância temporária sobre aquilo que se encontra em seus servidores. ${ }^{99}$

Por fim, vale apontar a afirmação de Guilherme Magalhães Martins ao concluir análise sobre o status dos integrantes da relação provedor autor do dano - vítima no cenário de regulamentação norte-americano e europeu:

"Observa-se, em suma, que, quando mais se limita a responsabilidade do provedor, na proporção inversa se aumenta a responsabilidade do usuário, cuja posição resta fortemente enfraquecida, diante disso as consequências do dano

${ }^{98}$ I ennardi Marcel On cit n 39 
terminam repousando sobre os ombros da própria vítima". 100

A atual formatação da referida legislação nos Estados Unidos e nos países membros da União Européia, obrigados a tomar como base as Diretivas 2001/29 e 2000/30, explica em parte porque nestes países as ações por indenização por danos em sede de sites de redes sociais direcionam-se mais aos autores do dano do que aos provedores. Outro motivo é por óbvio o estágio mais avançado em se tratando de regular relações por meio da Internet no qual se encontram os referidos países. 


\section{Análise da jurisprudência brasileira sobre responsabilidade civil em redes sociais.}

Enquanto aguarda a regulamentação da responsabilidade civil dos provedores de Internet, a jurisprudência brasileira tem se divido entre três correntes, a saber: (I) a não responsabilização, (II) a responsabilidade civil subjetiva, e (III) a responsabilidade objetiva.

Importa ressaltar que o foco do presente trabalho recái sobre a responsabilidade civil por ato de terceiro em sede de redes sociais no Brasil. De forma a empreender tal análise é preciso partir do entendimento sobre a responsabilização do provedor de serviços que disponibiliza o site de rede social. Para cada corrente verificada na jurisprudência buscar-se-á identificar o enquadramento das atividades desenvolvidas por estes sites, bem como a forma de responsabilidade civil atribuída.

Guilherme Magalhães Martins afirma que tanto os sites de rede social quanto aqueles dirigidos à divulgação de fotos e vídeos são considerados provedores de hospedagem ${ }^{101}$. No entanto, a definição tradicional de serviços de hospedagem ${ }^{102}$ parece não mais contemplar a amplitude de serviços que os sites de redes sociais acabam por prestar a seus usuários. Como exemplo cita-se o serviço de envio e recebimento mensagem do Facebook chamado "inbox". No mesmo sentido estão os aplicativos para diversos fins colocados à disposição do usuário também no Facebook.

\footnotetext{
${ }^{101}$ Martins, Guilherme Magalhães. Op. Cit., p. 284.

102 "Provedor de hospedagem é a pessoa jurídica que fornece o serviço de armazenamento de dados em servi-dores próprios de acesso remoto, possibilitando o acesso de terceiros a esses dados de arordo rom as condi- cões estahelecidas com o contratante do servico " Marcel
} 
O que se busca descobrir é se o provedor de serviços de Internet opera como mero intermediário ou não. Definição importante para a legislação norte-americana e para países sujeitos às Diretivas da União Européia, como já se viu na seção anterior. De acordo com Erica Barbagalo $^{103}$ não importa o quão complexo é o conjunto de serviços de armazenamento ofertados pelo provedor de serviços de hospedagem, mas sim o fato de não interferir no conteúdo do sites que hospeda. Esta questão é uma das chaves para a análise que se segue.

\subsection{A não responsabilização: o provedor como mero intermediário.}

Para Cavalieri a primeira questão a ser tratada envolvendo a responsabilidade civil é o nexo causal. ${ }^{104}$ É preciso antes de verificar a conduta culposa identificar se o agente deu causa ao resultado. Aqui parece se inserir as decisões que julgam o provedor de serviços de Internet como mero intermediário. Pode haver responsabilidade sem culpa, mas não pode haver responsabilidade sem nexo causal.

Há na doutrina uma pluralidade de teorias que explicam o nexo causal: teoria da equivalência das condições, teoria da causalidade adequada, e teoria da imputação do nexo causal. Porém, a jurisprudência usa indistintamente as teorias mencionadas, demandando como requisito básico do dever de indenizar existência de uma relação direta entre causa e dano. ${ }^{105}$

Importa ressaltar as palavras de Caio Mário da Silva Pereira ao observar a complexidade das questões que giram em torno do nexo causal:

\footnotetext{
${ }^{103}$ Barbagalo, Erica Brandini. Aspectos da Responsabilidade Civil dos provedores de serviços na Internet. In: Lemos, Ronaldo; Waisberg, Ivo (Org.). Conflitos sobre nomes de domínio e outras questões jurídicas da Internet. São Paulo: RT, 2003. P.347.

${ }^{104}$ Cavalieri Seroin Filho On $\mathrm{Cit}$ n 47
} 
"Este é o mais delicado dos elementos da responsabilidade civil e o mais difícil de ser determinado". ${ }^{106}$

O artigo 927 preceitua: aquele que comete ato ilícito tem o dever de indenizar. Cavalieri aponta duas premissas básicas para o tratamento das questões relacionadas responsabilidade civil: o descumprimento de uma obrigação, e a precisão do dever jurídico violado juntamente com quem o descumpriu. ${ }^{107}$

A partir da análise dos julgados que imputa qualquer responsabilidade ao provedor de serviços de hospedagem pelos danos causados por terceiros aos usuários dos sites de redes sociais que hospeda, entende-se que:

(I) o provedor de serviços de hospedagem é mero intermediário; e

(II) o provedor não tem nenhum dever de agir, portanto não há que se falar em responsabilidade civil subjetiva uma vez que a omissão não representará relevância causal; e

(III) o provedor não pode ser responsabilizado objetivamente pois não há conduta ilícita por parte dele, e consequentemente não há nexo causal entre o dano sofrido pelo usuário e a conduta do provedor.

A ilegitimidade passiva tem sido o argumento utilizado pelo Google, principal empresa colocada no pólo passivo das ações por responsabilidade civil envolvendo sites de redes sociais, uma vez que sustenta funcionar como mero intermediário, a exemplo do que se extrái do acórdão abaixo.

"No mérito, sustentou que é um site de hospedagem de páginas pessoais e de comunidades de interesse de seus usuários, portanto isenta de responsabilidade pelo conteúdo das informações veiculadas. Refutou a pretensão indenizatória,

${ }_{76}^{106}$ Pereira da Silva, Caio Mario. Responsabilidade Civil, 9. Ed. Rio de Janeiro, Forense, 2002. p. 
culminando por requerer a improcedência. Sobreveio proposta de decisão, opinando pela improcedência da ação". ${ }^{108}$

No entanto, em grau de recurso a sentença foi reformada para acolher a legitimidade da parte ré (Google) para figurar na ação. Em caso semelhante ao se pronunciar pelo afastamento da ilegitimidade pasiva do Google, a relatora salienta a diferença entre ilegitimidade de parte de improcedência da ação:

"A averiguação da legitimidade da parte demandada para tomar parte na lide, portanto, passa, necessariamente, pela análise dos fundamentos nos quais o autor baseia sua pretensão.(...) Da análise da inicial, portanto, outra conclusão não se tira a não ser que o demandado pode, em tese, responder à pretensão. (...)A partir do momento em que se analisa o nexo causal ou a existência de ato ilícito imputável à parte demandante, já se está a tratar do mérito, sendo equivocado, no entender desta julgadora, reconhecer a ilegitimidade passiva, quando, com efeito, é caso de julgamento de improcedência da ação". 109

No material pesquisado observa-se que quando há acolhimento da ilegitimidade passiva ad causum em lo grau, é comum a posterior reforma em sede de recurso. $\mathrm{Na}$ via reversa, quando o provedor em 2o grau pleiteia pela reforma objetivando ver sua ilegitimidade acolhida, tem como resultado o improvimento do recurso, conforme ementas a seguir:

EMENTA: REPARAÇÃO DE DANOS. SITE DE RELACIONAMENTO. "ORKUT". CRIAÇÃO DE PERFIL FALSO COM INTUITO DE DENEGRIR A IMAGEM DOS AUTORES. ILEGITIMIDADE PASSIVA AFASTADA. DANO MORAL CARACTERIZADO. QUANTUM INDENIZATÓRIO REDUZIDO. PRELIMINAR AFASTADA. RECURSO PROVIDO EM PARTE. UNÂNIME ${ }^{110}$.

EMENTA: PROCESSUAL CIVIL E CIVIL - APELAÇÃO - AÇÃO DE INDENIZAÇÃO POR DANOS MORAIS - SITE DE RELACIONAMENTO ORKUT - EXPOSIÇÃO DE IMAGEM - TEXTO DE CONTEÚDO PEJORATIVO E DIFAMATÓRIO - NÃO IDENTIFICAÇÃO DO USUÁRIO RESPONSABILIDADE DAS EMPRESAS PROPRIETÁRIAS DO SITE AGRAVO RETIDO - NÃO CONHECIMENTO - PRELIMINAR DE ILEGITIMIDADE PASSIVA - REJEIÇÃO - RESPONSABILIDADE CIVIL OBJETIVA - ARTS. 14, 20 E 23 DO CDC - TEORIA DO RISCO - DEVER DE INDENIZAR - RECONHECIMENTO - QUANTUM INDENIZATÓRIO -

108 TJRS. Recurso Cível No 71001408160, Rel.: Carlos Eduardo Richinitti, J. em 26/02/2008

109 Anelacão Cível No 70035979400. Relator Marilene Ronzanini Rernardi I em 24/11/7010 
PRUDÊNCIA E MODERAÇÃO - OBSERVÂNCIA NECESSÁRIA MAJORAÇÃO - CABIMENTO - $1^{\circ}$ RECURSO PROVIDO E $2^{\circ}$ RECURSO NÃO PROVIDO 111.

APELAÇÃO CÍVEL. AÇÃO DE OBRIGAÇÃO DE FAZER C/C INDENIZATÓRIA. RESPONSABILIDADE CIVIL. OFENSAS INSERIDAS POR ANÔNIMO NO SITE DE RELACIONAMENTOS "ORKUT". PRELIMINAR DE ILEGITIMIDADE PASSIVA AFASTADA. DANO MORAL CONFIGURADO ${ }^{112}$.

Relação de consumo. Responsabilidade civil. Ação de obrigação de fazer. Danos morais. Internet. Provedor de acesso. Legitimidade. Google. Sítio de relacionamento (Orkut). Criação de perfil falso. Terceiro. Mensagens ofensivas a integrantes da comunidade a que pertence o autor. Antecipação de tutela. Retirada do sítio falso. Indenização. (...) O Google Brasil Internet Ltda., que faz parte do mesmo grupo empresarial da Google, Inc., é parte legítima para figurar no pólo passivo da ação indenizatória que tem como fundamento ato ilícito praticado nos domínios do sítio eletrônico denominado Orkut, de que é proprietário. ${ }^{113}$ (grifo da autora)

Os excludentes da responsabilidade objetiva representam os principais argumentos presente na linha de defesa dos provedores de hospedagem de sites de redes sociais quando implicados em ações de indenização por fato de terceiro.

\subsection{A afirmação da responsabilidade civil subjetiva.}

Em consonância com o progresso social que torna a responsabilidade civil subjetiva fundada na culpa "insuficiente para a tutela das relações jurídicas na sociedade de massa"114, o Código Civil de 2002 privilegia a responsabilidade objetiva. No entanto, mantém uma cláusula geral de responsabilidade subjetiva, extraída da conjugação do artigo 927, CC com artigo 186, CC.

\footnotetext{
${ }^{111}$ TJMG. Apelação cível n 1.0024.07.794839-6/001 - relatora: Desª . Márcia de Paoli Balbino. J. em $02 / 10 / 2010$.

${ }^{112}$ TJRJ. Apelação n. 0006047-50.2009.8.19.0040 - Des. Benedicto Abicair. J. em: 01/12/2010 -

113 TJRJ. Apelação n. 0374854-06.2008.8.19.0001 (2009.001.69800)- Des. Mario Assis Foncalves I em $72.06 / 2010$ -
} 
$\mathrm{O}$ artigo 186, CC traz o ato ilícito como fundamento da responsabilidade subjetiva. A composição do ato ilícito segundo a doutrina comporta três elementos: (a) conduta culposa ou dolosa em confronto com a norma jurídica, (b) dano, e (c) nexo de causalidade entre conduta e dano. ${ }^{115}$ Apesar do conceito de culpa ser único, ela pode se exteriorizar de três modos principais: imprudência, negligência e imperícia. No casos em tela, a culpa imputada aos provedores diz respeito à negligência como se verá adiante.

O dever de indenizar na responsabilidade subjetiva está atrelado portanto a verificação de existência de cada um dos pressupostos do ato ilícito. Identificando a ocorrência do dano ${ }^{116}$, valorando a conduta culposa $^{117}$ do agente, e o nexo causal. Nos julgados que se seguirão, a responsabilidade civil subjetiva é justificada pela relação direta identificada entre o dano, em grande parte lesão a direitos personalíssimos do usuário de sites de redes sociais, e a negligência do provedor de serviços que hospeda os referidos sites.

A conduta culposa do provedor de serviços de Internet nos casos em tela deriva portanto da omissão, pela inércia quando deveria agir para impedir o resultado danoso. Concretamente, o que se verifica na corrente jurisprudencial que afirma a responsabilidade civil subjetiva do provedor é a clara indicação de culpa quando, por exemplo, o conteúdo ilícito não é retirado ou bloqueado quando o site é notificado pelo usuário.

A ementa abaixo trata de ação indenizatória movida por uma usuária em face do Orkut que viu seu perfil ser alterado com a inclusão de conteúdo ilícito. $\mathrm{O}$ entendimento da relatora foi no sentido de confirmar a sentença

\footnotetext{
${ }^{115}$ Tepedino, Gustavo; Barboza, Heloisa Helena; Bodin de Moraes, Maria Celina: Código Civil Interpretado, vol 1. Ed Renovar, 2006, p. 333.

116 Definido nelo doutrina como lesão a um hem iurídico
} 
prolatada em 1a instância que conferiu ganho de causa a autora, afirmando que "é dever da requerida manter esforços para repelir tais atos ou, ao menos, não oportunizar a visita do grande público à página pessoal que está sob suspeita".

"REPARAÇÃO DE DANOS. SITE DE RELACIONAMENTO "ORKUT". ALTERAÇÃO FRAUDULENTA DE PERFIL PESSOAL COM INTUITO DE LESAR A IMAGEM DA AUTORA. PERFIL COM DESCRIÇÃO DE CUNHO SEXUAL E OFENSIVO À DIGNIDADE. COMPROVADA A INÉRCIA DA EMPRESA QUE HOSPEDA A REDE SOCIAL EM EXLUIR A PÁGINA PESSOAL DA USUÁRIA, A DESPEITO DOS PEDIDOS E DENÚNCIAS DE ABUSO. DANO MORAL CARACTERIZADO. QUANTUM MANTIDO, POIS RAZOÁVEL Á EXTENSÃO DO DANO. RECURSO IMPROVIDO”. 118

A omissão da parte ré frente à notificação da parte autora é o fundamento utilizado para sua responsabilização subjetiva e consequente dever de indenizar. $\mathrm{O}$ voto da relatora está consonância com a essência da responsabilidade subjetiva que busca, segundo Caio Mario da Silva Pereira, descobrir como o comportamento do agente contribui para o dano sofrido pela vítima. ${ }^{119}$

Vale ressaltar que o conteúdo ilícito e ofensivo acabou por ser retirado pelo Orkut, porém isto só foi feito após o recebimento de ordem judicial, conforme se assinala:

"A ré não nega que a autora tenha reportado o abuso em seu perfil pessoal, e, embora não exista data específica no processo acerca de que data isso ocorreu, extrai-se tenha sido em dezembro de 2009. A ré, por sua vez, confirma que só excluiu a página do "Orkut" em 13 de janeiro de 2010 (fl. 141), após receber determinação judicial.”

A necessidade ou não de notificação por meio de ordem judicial é

${ }^{118}$ TJRS, Recurso Cível No 71002629533. Rel: Vivian Cristina Angonese Spengler, j. em 24/02/2011.

${ }^{119}$ Pereira Cain Márin da Silva Pereira Resnnnsahilidade Civil Rin de Ianeirn Forense 9a 
polêmico, tendo sido inclusive fonte de discussão e reformulação do artigo do anteprojeto do Marco Civil na Internet brasileira que tratou da questão, como se verá no próximo capítulo do presente tarabalho. O modelo norteamericano como já se viu na seção antecedente prevê a possibilidade de notificação extrajudicial por parte do usuário em caso de verificação de conteúdo ilegal, desde que cumpridos uma série de requisitos formais.

Em outro acórdão também do TJRS o desembargador isenta o provedor de serviços de hospedagem e o site de rede social (novamente o Google / Orkut) do dever de indenizar usuário que teve página criada com informações inverídicas sobre sua pessoa. $\mathrm{O}$ argumento que sustenta a não responsabilização do provedor é baseado na falta de comunicação formal ao Orkut sobre o ocorrido, conforme se lê na referida ementa:

“APELAÇÃO CÍVEL. RESPONSABILIDADE CIVIL. ORKUT. CRIAÇÃO DE PÁGINA. OFENSA INSERIDA POR TERCEIRO. Não tendo a parte autora demonstrado que o demandado foi notificado formalmente acerca das informações veiculadas na comunidade criada, ônus que competia à suplicante, nos termos do artigo 333, I, do CPC, restando incomprovada a conduta omissiva do provedor, não há falar em dever de indenizar deste. Precedentes desta Corte. Sentença de improcedência mantida. APELAÇÃO IMPROVIDA." ${ }^{20}$ (grifo da autora)

Neste sentido Marcel Leonardi afirma que:

"A responsabilidade dos provedores de hospedagem por atos ilícitos praticados por seus usuários é subjetiva, advindo apenas de eventual conduta omissiva, de negligência ou imprudência, tendo aplicação o art. 186 do Código Civil. Isto ocorrerá quando o provedor de hospedagem deixar de bloquear o acesso à informação ilegal disponibilizada por um usuário, ou quando não o fizer em tempo hábil, desde que tenha sido previamente informado a esse respeito e desde que não haja dúvidas sobre a ilicitude da conduta perpetrada pelo usuário". ${ }^{121}$

Em outubro de 2010 a 4a Câmara Cível do TJSP firmou entendimento no sentido de privilegiar a obrigatoriedade da notificação sobre conteúdo ilícito por parte de quem sofre a ofensa, e a consequente

${ }^{120}$ TJRS. Apelação Cível No 70036809721, Relator: Paulo Roberto Lessa Franz, J. em 16/12/2010 
obrigação do provedor de hospedagem de retirar tal material. $\mathrm{O}$ autor da ação, o piloto Rubens Barrichello, vítima de uma série de perfis falsos e de comunidades ofensivas dirigidas a sua pessoa criadas no Orkut, solicitou ao Google a retirada de tais páginas.

Mesmo entendendo que a responsabilidade pelo conteúdo das páginas é do usuário, o relator da apelação ressalta quando a ré no caso em tela passa a ser passível de responsabilização:

"no exato momento em que, tomando ciência do conteúdo ilícito dos perfís e comunidades, nega-se a retirá-los, sem justificativa plausível. Nasce daí a responsabilidade civil da ré de tomar imediatas e prontas providências para coibir o comportamento do intemauta, tão logo chegou ao seu conhecimento que o nome do autor vinha sendo mal utilizado por terceiros". ${ }^{122}$

No mesmo sentido se pronunciou o STJ ao julgar o REsp 1193764/SP, que envolveu o ajuizamento de ação indenizatória de usuária em face do Google para que retirasse do Orkut informações consideradas ofensivas a sua pessoa, conforme se extrái do voto da ministra Nancy Andrighi:

"Houve a concessão de tutela antecipada, para o fim de determinar a "exclusão de todo o material ofensivo que relacione o nome da autora" (fl. 148, e-STJ), tendo o GOOGLE prontamente dado cumprimento à ordem judicial, esclarecendo que a comunidade onde estavam sendo veiculadas as informações "foi removida em 28 de abril do corrente ano" (fl. 195, e-STJ). Nesse ponto, portanto, não houve ilegalidade nos atos praticados pelo GOOGLE que, uma vez ciente da existência de material de conteúdo ofensivo, adotou todas as providências tendentes à sua imediata remoção do site". ${ }^{123}$

Em caso semelhante que remonta a criação de comunidade com conteúdo ofensivo à honra e a imagem de usuário do Orkut, o TJRJ também entendeu que o provedor comete ato ilícito ao não retirar o referido material quando avisado pela autora sobre seu teor. É aplicada a responsabilidade subjetiva, conforme voto demonstrado no voto do relator do processo:

122 TISP An 0701970-38 2006 8 260100 
"Responsabilidade que decorre do desinteresse em averiguar a denúncia feita pela autora, tendo em vista reconhecer-se a impossibilidade de controle prévio de todos os dados lançados no site de relacionamentos. Hipótese de aplicação da responsabilidade subjetiva prevista nos artigos 186 e 927, caput do Código Civil". ${ }^{124}$

O TJMG em casos similares nos anos de 2009 e 2010 já decidiu pela ilegitimidade passiva do Google / Orkut quando não há violação de deveres, adotando a responsabilidade subjetiva como forma de responsabilização como aduz o extrato da seguinte ementa:

“APELAÇÃO CÍVEL. INDENIZAÇÃO POR DANOS MORAIS. INTERNET. OFENSAS VEICULADAS NO ORKUT. RESPONSABILIDADE SUBJETIVA. ILEGITIMIDADE PASSIVA DO PROVEDOR. - O operador do site, em regra, como no caso do orkut, não tem um controle editorial prévio, mas somente a posteriori, quando toma conhecimento do que foi efetivamente publicado. Por isso, somente pode ser responsabilizado quando tem conhecimento real do caráter ilícito ou algum motivo para desvendar a natureza da informação... É a partir deste momento, em que é informado do caráter danoso da informação hospedada em seu sistema, que tem a obrigação de tomar todas as medidas necessárias para prevenir danos ou retirá-la, sob pena de ser responsabilizado por negligência". ${ }^{125}$

A responsabilidade subjetiva como já seu viu funda-se na culpa, e é nesse element, segundo Caio Mário da Silva Pereira, que é feita a distinção em relação a responsabilidade objetiva. ${ }^{126}$ É recorrente nos julgados que aplicam a responsabilidade subjetiva aos provedores de Internet a menção à impossibilidade técnica de fiscalização do conteúdo presente em seus sites de redes sociais.

Marcel Leonardi afirma que os provedores de hospedagem tem o dever de não monitorar dados e conexões estabelecidos em seus servidores, conforme assinala:

"O monitoramento de dados e conexões representa verdadeira interceptação de comunicação e, como tal, somente pode ser efetuado para fins penais, nos termos

${ }^{124}$ TJRJ. APELAÇÃO CÍVEL No: 2009.001.47765. Rel: Des. Marco Aurélio Dos Santos Fróes. J. em 09/02/2010.

${ }^{125}$ TIMG An 1007407 483036-5/001: Rel Des Pedro Rernardes i em 07/04/2009 
do art. $5^{\circ}$, inciso XII, da Constituição Federal, regulamentado para esses fins pela Lei Federal n. 9.296/1996". ${ }^{127}$

Portanto o monitoramento não faz parte dos deveres atribuídos aos provedores dos serviços em tela. A este respeito o STJ já se manifestou: “A fiscalização prévia, pelo provedor de conteúdo, do teor das informações postadas na web por cada usuário não é atividade intrínseca ao serviço prestado....".128

Da mesma forma assinala o TJRS, em sede de apelação tratando da responsabilidade do Orkut por páginas de conteúdo ofensivo, sobre não a obrigatoriedade da fisalização prévia ressaltando a contrariedade com o direito à liberdade de expressão:

"De outro modo, inexiste norma que impute ao provedor de serviço o dever legal de monitoramento das comunicações, esse procedimento seria inviável do ponto de vista jurídico, pois implicaria negar aplicação ao princípio constitucional da livre manifestação de pensamento." 129

Logo, as ações de indenização em face dos sites de redes sociais que alegam a inobservância do dever de cuidado por não monitorar conteúdo não prosperam. Não apenas pelo fator imposto pela dificuldade técnica, mas também por outros motivos relevantes: (I) o controle editorial seria equiparado a uma censura prévia, o que fere a liberdade de expressão garantida constitucionamente (II) o juízo de valor é subjetivo, (III) acaba com uma das vantagens da transmissão de informações pelo meio digitial: a simultâneidade e a falta de um centro de controle.

Sobre o tema fiscalização de conteúdo importa ainda ressaltar três questões assinalas por Carlos Affonso de Souza Pereira: ${ }^{130}$

\footnotetext{
${ }^{127}$ Leonardi, Marcel. Op.Cit. p.56.

${ }^{128}$ STJ. Resp 1.193.764. Rel. Min. Nancy Andrighi, j. em 14/12/2010.

129 TIRS Anelacão Cível No 70033703100 Rel · Tasso Cauhi Soares Delaharv i em 12/05/7010
} 
(I) A fiscalização não funciona: não existem meios que garantam que um conteúdo não será mais exibido. Há no mercado um sem número de mecanismos tecnológicos capazes de burlar os filtros estabelecidos por um provedor.

(II) A fiscalização extrapola os motivo iniciais de implementação tendendo a prejudicar a exbição de conteúdo lícito.

(III) A fiscalização impacta negativamente na neutralidade da rede.

Cabe ressaltar porém que a não obrigatoriedade de fiscalização prévia por parte do provedor de serviços não se contrapõe ao dever do provedor de hospedagem de guardar os dados de conexão necessários para a identificação do usuário. ${ }^{131}$

Em acórdão já mencionado anteriormente que trata de dano à imagem do piloto Rubens Barrichello em comunidades ofensivas criadas no Orkut há clara afirmação por parte do relator sobre a obrigatoriedade de revelação da identidade dos ofensores: "Há, assim, uma cláusula geral imposta aos intermediários, que assim pode ser resumida: "há o ônus de identificar os usuários que transitam pela rede". Justifica sua posição citando Ricardo Lorenzeti:

\footnotetext{
"a regra de identificação constitui um ônus que se impõe àquele que estiver em melhores condições de cumpri-la com os menores custos. Neste caso, são os intermediários que podem desempenhar este papel, uma vez que tem a possibilidade de estabelecer critérios, pautas e filtros para que os usuários sejam identificáveis" (Comércio Eletrônico, RT, p.440). ${ }^{132}$
}

Em síntese, da parcela de jurisprudência analisada para o presente trabalho, que se coaduna com a responsabilidade subjetiva do provedor de serviços que hospeda site de rede social, pode-se extrair as seguintes conclusões:

${ }^{131}$ I ennardi Marcel On Cit n 57 
(I) É dever do provedor de hospedagem estar atento às notificações que recebe por parte dos usuários sobre conteúdo ilegal e empreender esforços para retirar ou bloquear o acesso.

(II) A responsabilidade para o provedor nasce a partir do momento em que é notificado sobre conteúdo ilegal.

(III) Não faz parte dos deveres dos provedores a fiscalização de conteúdo sem que haja provocação.

(IV) A liberdade de expressão, a subjetividade acerca de conteúdo ofensivo, e a dificuldade técnica de monitoramento por parte do provedor são justificativas recorrentes pela parcela da jurisprudência que se coaduna com a resposabilidade subjetiva do provedor.

\subsection{A responsabilidade objetiva do provedor.}

A responsabilidade objetiva entra em pauta a partir do final do século XIX quando começa a ficar claro que a prova da culpa por parte da vítima é o grande impeditivo das indenizações. Desde então uma série de esforços são feitos para amenizar a necessidade de prova, até o momento em que surge positivação da responsabilidade sem culpa em certos ordenamentos. ${ }^{133}$

\subsubsection{CDC e a decisão do STJ sobre o Orkut.}

O caminho percorrido para se chegar a reponsabilidade civil objetiva presente no Código Civil de 2002 por meio do artigo 927, passou conforme observa Marcelo Calixto: "pela elaboração de leis especiais que simplesmente negavam ao instituto da culpa o papel de pressuposto da

\footnotetext{
${ }^{133}$ Calixto Marcelo Iuncueira A culna na resnonsahilidade civil - estrutura e funcão Rio de
} 
responsabilidade civil". ${ }^{134}$

O legislador regulamentou inicialmente a responsabilidade do transportador ferroviário, para em seguida a tratar de: acidentes de trabalho, mineração, veículos, atividades nucleares, atividades lesivas ao meioambiente, transporte aéreo, e por fim das relações de consumo por meio do Código de Defesa do Consumidor - CDC. Sem esquecer da responsabilidade objetiva atribuída no artigo 37 § 60 da Constituição Federal de 1988 às pessoas de direito público e àquelas de direito privado que prestam serviços públicos. ${ }^{135}$

Para o objetivo do presente trabalho, importa buscar os fundamentos presentes na jurisprudência para a incidência ou não do CDC nas relações estabelecidas entre usuário e sites de redes sociais.

Em janeiro de 2011 os ministros da Terceira Turma do STJ em decisão relacionada a pedido de indenização por danos morais de usuária ajuizado em face da Google Brasil, trouxeram a luz os seguintes pontos de relevância para a dicussão em tela:

(a) é de consumo a relação entre usuário e provedor: "Parece inegável que a exploração comercial da Internet sujeita as relações jurídicas de consumo daí advindas à Lei no 8.078/90."136

(b) a gratuidade do serviço prestado pelo Google por meio do Orkut não descaracteriza a relação de consumo:

"Vale notar, por oportuno, que o fato de o serviço prestado pelo provedor ser

\footnotetext{
${ }^{134}$ Calixto, Marcelo Junqueira. A culpa na responsabilidade civil - estrutura e função. Rio de Janeiro: Renovar, 2008. p. 154.

${ }^{135}$ Moraes, Maria Celina Bodin de. Risco, Solidariedade, Responsabilidade Objetiva. p. 13. In: Revista dos Trihunais São Pauln Revista dos Trihunais Vol 854 nn 11-37 Dezemhro de 2006
} 
gratuito não desvirtua a relação de consumo, pois o termo "mediante remuneração" contido no art. $3^{\circ}, \S 2^{\circ}$, do CDC deve ser interpretado de forma ampla, de modo a incluir o ganho indireto do fornecedor."137

(c) a responsabilidade do Google é restrita às atividades desenvolvidas no Orkut:

"Nesse aspecto, o serviço do GOOGLE deve garantir o sigilo, a segurança e a inviolabilidade dos dados cadastrais de seus usuários, bem como o funcionamento e a manutenção das páginas na Internet que contenham as contas individuais e as comunidades desses usuários."138

(d) a fiscalização do conteúdo não é atividade intrínseca ao Google:

"No que tange à fiscalização do conteúdo das informações postadas por cada usuário, não se trata de atividade intrínseca ao serviço prestado, de modo que não se pode reputar defeituoso, nos termos do art. 14 do CDC, o site que não examina e filtra o material nele inserido." 139

No recurso especial acima relatado, a ministra Nancy Andrighi negou provimento e afirmou que no caso concreto em tela o Google Brasil não podia ser responsabilizado pelas ofensas dirigidas a autora da ação.

Em seguida, em março de 2011, o STJ, na figura do ministro João Otávio de Noronha, ao julgar outra ação da mesma natureza, negou provimento ao agravo de instrumento interposto pelo Google contra decisão que inadmitiu recurso especial em face de acórdão do TJRJ e reafirmou ser de consumo a relação entre usuários e sites de redes sociais. No entanto, desta vez o Google se viu obrigado a indenizar o usuário por danos morais:

"Quanto à aplicabilidade do Código de Defesa de Consumidor, entende-se pela sua possibilidade. Embora a relação estabelecida entre as partes não possua remuneração direta, é notório que a remuneração se opera de forma indireta, na medida em que terceiros utilizam seus serviços para promover anúncio, tendo em vista o elevadíssimo número de acessos em seu site. A partir do momento em que a apelante não cria meios de identificação precisa do usuário, mas permite a

${ }^{137}$ STJ. RESP No 1.193 .764 - SP. Min. Nancy Andrighi. J. em 14/12/2010 fls 6.

${ }^{138}$ Idem fls 7 
criação de páginas pessoais em seu site, beneficiando-se, ainda que indiretamente como dito acima, entende-se que ela assume o ônus pela má utilização dos serviços que disponibiliza, independentemente da existência de culpa. Sentença que se mantém". ${ }^{140}$

Fica claro a partir dos dois julgados do STJ acima relatados que não basta a definição pela aplicação do Código de Defesa do Consumidor às relações entre provedores de serviços de Internet e usuários. É preciso mais do que isso, é fundamental a uniformização dos conceitos de consumidor, fornecedor e do entendimento do escopo dos serviços contemplados nas atividades dos referidos sites.

Não é pacífico na doutrina a amplitude de aplicação do CDC. Para Cavalieri o CDC é "uma sobre-estrutura jurídica multidisciplinar" aplicável sempre que se verificar a relação de consumo ${ }^{141}$. Neste sentido, Claudia Lima Marques afirma que “...estão submetidos às regras do Código os contratos firmados entre o fornecedor e o consumidor não-profissional...”. 142

A polêmica em torno da aplicação do $\mathrm{CDC}$ aos casos entre usuário e site de rede social gira em torno da gratuidade do serviço em tela, e portanto da não caracterização da relação de consumo. $O$ § 20 do art 30 CDC é claro ao excluir a atividade não remunerada do conceito de serviço:

$\S 2^{\circ}$ Serviço é qualquer atividade fornecida no mercado de consumo, mediante remuneração, inclusive as de natureza bancária, financeira, de crédito e securitária, salvo as decorrentes das relações de caráter trabalhista.

No entanto, Cavalieri ${ }^{143}$ assinala a diferenciação entre serviço puramente gratuito e serviço aparentemente gratuito, onde o prestador

\footnotetext{
${ }^{140}$ STJ. Agravo de Instrumento N. 1.347 .502 - RJ. Ministro João Otávio de Noronha. J. em $14 / 03 / 2011$.

${ }^{141}$ Cavalieri, Sergio. Op. Cit. p. 449.

${ }^{142}$ Marques, Claudia Lima. Contratos no Código de defesa do consumidor: o novo regime das relacões contratıais 5a ed São Paulo• Fditora Revista dos Trihunais 2005 P 705
} 
obtém uma vantagem patrimonial indireta. Parece ser este o caso dos sites de redes sociais. A linha da jurisprudência que vem aplicando o CDC e por conseguinte a responsabilidade objetiva aos sites de redes sociais se coaduna com a ideia da remuneração indireta.

No sentido de privilegiar os ganhos indiretos e aplicar o CDC em ação ajuizada por usuário que teve seu perfil no Orkut adulterado, decidiu o TJRO em julho de 2010:

"Internet. Serviço. Falha. Código de Defesa do Consumidor. Aplicabilidade. Site de relacionamento. Perfil adulterado e ofensivo. Pedido de bloqueio e exclusão feito por usuário. Não atendimento. Dano moral. Valor. Fixação. Evidenciado que a empresa Google obtém remuneração indireta pelo serviço Orkut, por meio da divulgação de propagandas e do nome da própria empresa, o que certamente contribui para que este aufira ganhos econômicos, caracteriza serviço nos termos da legislação consumerista, permitindo, por conseguinte, a aplicação do Código de Defesa do Consumidor em demanda visando indenização por ofensas irrogadas em perfil falso". ${ }^{144}$

É notório que quanto maior a audiência de um site, ou de qualquer veículo de comuncação, mais este site poderá cobrar pela inserção publicitária em seu espaço. Porém os sites de redes sociais detem outro ativo de significativo valor comercial: as informações inseridas pelos próprios usuários. Por exemplo: ao usar o aplicativo do Facebook "frases de Chico Xavier" ${ }^{145}$ o usuário autoriza que o desenvolvedor do aplicativo tenha acesso a nome, foto de perfil, gênero, redes, ID de usuário, lista de amigos e qualquer outra informação tenha sido compartilhada publicamente no site.

Estes ativos de remuneração indireta são as chamadas "novas moedas" conforme observa Martins:

\footnotetext{
${ }^{144}$ TJRO. Apelação. 0055801-94.2009.8.22.0001. Des. Rel. Marcos Alaor Diniz Grangeia. J. em 14/07/2010.

${ }^{145} \mathrm{http}: / /$ www.facebook.com/connect/uiserver.php?app id=223009653857\&next=http\%3A\%2F\% 2Fquotes.mysocialsoftware.com\%2F\%3Fref\%3Dindex\%26app\%3D223009653857\&display=page \&lncale=nt RR\&nerms\&return session=0\&fhconnect=0\&canvas $=1 \&$ leoacv return $=1 \& \mathrm{method}=$
} 
"Diante de tais formas de contratação, cuja gratuidade é infirmada pela existência de um correspectivo prestado pelo consumidor, pode-se falar em uma nova moeda, entendida como instrumento de pagamento e troca, que consiste, diretamente, nas informações pessoais e econômicas que nos pertencem e, indiretamente, no nosso poder aquisitivo, contribuindo para aumentar a capacidade de penetração dessas empresas no mercado". ${ }^{146}$

Configurada a relação de consumo, o sistema de responsabilidade está definido: O CDC estabelece responsabilidade objetiva para todos os casos de acidente de consumo, quer por fato do produto (art 12) quer por fato do serviço (art 14). É a teoria do risco do empreendimento: "todo aquele que se disponha a exercer alguma atividade no mercado de consumo tem o dever de responder pelos eventuais vícios ou defeitos dos bens e serviços fornecidos, independentemente de culpa". ${ }^{147}$

Neste sentido observa-se a decisão do TJMG em janeiro de 2011 sobre o recorrente caso de ofensas postadas no Orkut sem que seja possível a identificação do responsável. Segue ementa:

TEORIA DO RISCO - DEVER DE INDENIZAR - RECONHECIMENTO QUANTUM INDENIZATÓRIO - PRUDÊNCIA E MODERAÇÃO OBSERVÂNCIA NECESSÁRIA - MAJORAÇÃO - CABIMENTO - $1^{\circ}$ RECURSO PROVIDO E $2^{\circ}$ RECURSO NÃO PROVIDO. ${ }^{148}$ (grifos da autora)

Em outro acórdão verifica-se entendimento similar quanto à forma de responsabilização da mesma parte ré (Google / Orkut) pelo mesmo tema (criação de perfis falsos / conteúdo ofensivo), a saber:

AÇÃO DE INDENIZAÇÃO. DANO MORAL. ORKUT. REDE SOCIAL. SÍTIO DE RELACIONAMENTO. INTERNET. PROVEDOR DE SERVIÇOS DE INFORMAÇÕES. RESPONSABILIDADE POR FATO DO SERVIÇO. DIREITO DO CONSUMIDOR. RESPONSABILIDADE OBJETIVA. USUÁRIO VÍTIMA DO EVENTO. OFENSAS DE CUNHO MORAL. EXPRESSÃO ""FAZENDO A FILA ANDAR"". QUANTUM. ${ }^{149}$

\footnotetext{
${ }^{146}$ Martins, Guilherme Magalhães. Op. Cit. p. 83.

${ }^{147}$ Cavalieri, Sergio. Op. Cit. p. 459.

${ }^{148}$ TJMG. Apelação. 1.0024.07.794839-6/001(1) . Rel. Des. Marcia de Paoli Balbino. J. em $07 / 12 / 2010$
} 
Neste ponto retoma-se o voto de Nancy Andrighi para assinalar que a ministra não concorda que a atividade do provedor seja de risco: "Tampouco se pode falar em risco da atividade como meio transverso para a responsabilização do provedor por danos decorrentes do conteúdo de mensagens inseridas em seu site por usuários."150 Reforça-se mais uma vez que a definição da incidência ou não do CDC não é suficiente em si mesma para indicar com clareza como se posiciona a corrente da jurisprudência em questão.

A discussão também passa pela via do que é acidente de consumo em matéria de redes sociais e qual é o dever violado por parte do fornecedor. Em acórdão do janeiro de 2011, o TJMG entendeu que a criação de pefil falso é acidente de consumo, e que o fornecedor (Google) tem dever de prover este nível de segurança ao usuário:

"No caso, não há dúvida de que o responsável principal e direto pela ofensa é o usuário, criador do mencionado perfil difamatório. Entretanto, a ré, ora apelante, não se exime da responsabilidade de indenizar a autora/apelada, na medida em que ficou cabalmente demonstrado que o serviço por ela prestado é falho, vez que não garante ao usuário a segurança necessária, permitindo a veiculação de mensagens de conteúdo extremamente ofensivos e desabonadores."151

No que tange a responsabilidade do fornecedor de produtos e serviços, $\mathrm{O}$ CDC rompeu com clássica dicotomia doutrinária que dividia a responsabilidade em contratual e extracontratual. O artigo 17, CDC, equipara as vítimas do acidente de consumo e impõe ao fornecedor um tratamento único uma vez que trata-se de violação do dever de segurança. Segundo Cavalieri: "o defeito do produto ou serviço lançado no mercado e que, numa relação de consumo, contratual ou não, dá causa a um acidente

${ }^{150}$ STJ. RESP N ${ }^{\mathrm{o}} 1.193 .764$ - SP. Min. Nancy Andrighi. J. em 14/12/2010. fls 6.

151 TIMG Anelacão 1007407 794839-6/001(1) Rel Des Marcia de Panli Ralhinn I em 
de consumo." 152

Não é pacífico portanto na doutrina a aplicação do CDC às relações entre provedores de serviços de redes sociais e usuários, muito menos às relações entre usuários de redes sociais e os provedores que hospedam os sites das respectivas redes sociais. Enquanto há entendimento que a aplicação do legislação consumerista seria óbvia por se tratar da oferta de um serviço que apresenta remuneração, ainda que indireta, há também a noção de que é uma prestação a título gratuito que não ensejaria a incidência do mesmo.

\subsubsection{A teoria do risco: artigo 927, parágrafo único.}

O Código Civil de 2002 no que tange a responsabilidade civil trouxe junto com a cláusula geral da culpa (art. 927 caput) outra regra geral, esta fundada no risco da atividade desenvolvida, conforme positivada no parágrafo único do artigo $927:{ }^{153}$

Haverá obrigação de reparar o dano, independente de culpa, nos casos especificados em lei, ou quando a atividade normalmente desenvolvida pelo autor do dano implicar, por sua natureza, risco para os direitos de outrem.

De acordo com Cavalieri "risco é perigo, é probabilidade de dano" ${ }^{154}$, e para explicar a ideia de risco surgiram várias teorias relacionadas ao parágrafo único do $927, \mathrm{CC}$ : risco criado, risco proveito, risco emprenndimento, risco profissional, risco excepcional, risco integral entre outras.

A teoria do risco proveito afirma ser responsável aquele que se beneficia de alguma forma da atividade danosa, recorrendo a máxima:

${ }^{152}$ Cavlieri, Sergio. Op. Cit. p. 16.

153 Moraes Maria Celina Rodin de On Cit n 14 
“onde está o ganho, aí reside o encargo". Cavalieri ressalta que esta teoria não especifica qual tipo de benefício seria necessário ser verificado para a consequente responsabilização. Em se tratando de vantagem econômica a aplicação ficaria restrita aos comerciantes e industriais, o que seria restrito por demasia. ${ }^{155}$

A teoria do risco profissional relaciona o dever de indenizar ao exercício de uma atividade profissional determinada, o que também seria restritivo. A teoria do risco excepcional trata das atividades que representam riscos fora do comum, a exemplo do trabalho com redes elétricas e com energia nuclear. A teoria integral, a mais extremada dentre todas as teorias, é a aquela que não admite nenhuma excludente de responsabilidade.

Por fim, a teoria do risco criado que delega responsabilidade àquele que com a atividade que empreende expõe outrem a risco. Mesmo que não haja lucro, se há exposição a risco, pela teoria do risco criado há dever de indenizar. Assinala Caio Mário da Silva Pereira ao externar sua filiação à esta teoria:

"A teoria do risco criado importa em ampliação do conceito do risco proveito. Aumenta os encargos do agente; é, porém, mais equitativa para a vítima, que não tem de provar que o dano resultou de uma vantagem ou de um benefício obtido pelo causador do dano. Deve este assumir as consequências de sua atividade". ${ }^{156}$

Não é pacífico na doutrina qual a teoria do risco adotado pelo Código Civil, a polêmica paira entre o risco-criado e o risco proveito. Neste sentido Gustavo Tepedino afirma que cabe a doutrina e a jurisprudência o entendimento do alcance das expressões utilizadas no parágrafo único do artigo 927 que definem a responsabilidade civil objetiva. Além da teoria do risco aplicada discute-se também qual seria o conceito de "atividade

155 Cavalieri Seroin On Cit n 179 
normalmente desenvolvida" bem como a noção de risco da atividade. ${ }^{157}$

Maria Celina Bodin de Moraes esclarece que "atividade normalmente desenvolvida" deve ser lida como "atividade organizada", conforme observa:

"No estágio atual de nossa sociedade, o desenvolvimento continuado (não eventual ou errático) de qualquer atividade demanda, e impõe, a sua organização. Nestes casos não tem sentido isolar um comportamento, gerador em concreto do dano, sem referi-lo à inteira atividade em virtude da qual o dano ocorreu". ${ }^{158}$

Para Cavalieri o conceito de atividade posto no dispositivo em questão (parágrafo único do art. 927) refere-se a "conduta reiterada, habitualmente exercida, organizada de forma profissional ou empresarial para realizar fins econômicos"159. A finalidade econômica é o centro da teoria do risco proveito ao propor que só pode ser responsabilizado pela ocorrência de dano aquele que extrái da atividade desempenhada algum benefício ou lucratividade. 160

Já para Maria Celina Bodin de Moraes, a distinção entre atividade lucrativa e não lucrativa é inconcebível, pois se opõe ao fundamento da responsabilidade objetiva que é garantir ampla tutela à vítima. ${ }^{161}$

A discussão sobre o que pode ser classificado como atividade de risco é de especial interesse para o presente trabalho, pois parte da jurisprudência afirma ser de risco o negócio dos sites de redes sociais. Porém nos julgados pesquisados para o presente trabalho, é possível verificar que a jurisprudência pouco aprofunda a análise da existência ou não do risco nas atividades desenvolvidas pelos provedores de serviços de Internet, sejam eles de conteúdo ou tão somente de hospedagem. O que se

\footnotetext{
157 Tepedino, Gustavo et all. Op. Cit. p. 809.

${ }^{158}$ Moraes, Maria Celina Bodin. Op. Cit. p. 28.

${ }^{159}$ Cavalieri, Sergio. Op. Cit. p. 155.

160 Tenedino Gustavo et all On Cit n 807
} 
verifica é tão somente a menção do termo "risco" para justificar a aplicação da responsabilidade objetiva em conformidade com o parágrafo único do art. 927, CC.

Exceções foram encontradas nos Tribunais de Minas Gerais e do Rio

Grande do Sul, conforme explicitam os acórdãos que se seguem.

"Assim, tenho que a empresa apelante ao disponibilizar espaço em sites de relacionamento virtual, em que seus usuários podem postar qualquer tipo de mensagem, sem prévia fiscalização, com conteúdos ofensivos e injuriosas e muitas vezes, com procedência desconhecida, assume o risco de gerar danos a outrem, sendo de se aplicar ao caso sub judicie, portanto, a referida teoria do risco, a qual defende a responsabilidade objetiva daquele que extrai lucro com o exercício da atividade que gera margem ao dano". ${ }^{162}$ (grifo da autora)

Ressalta-se que os dois julgados em tela lançam mão da teoria do risco proveito, pois são claros na menção ao lucro ou ao benefício de empreederem tais atividades.

"Porém, tratando-se de atividade de risco - com a qual a ré aufere lucro, destaque-se - em que qualquer pessoa pode facilmente criar falsos perfis, causando, assim, dano à honra e imagem de outrem, é caso de responsabilidade civil objetiva, nos termos do art. 927, parágrafo único, do CPC. Ou seja, se este risco é inevitável e a ré o assume, diante dos benefícios que obtém, responde pelos prejuízos" $"$.

A ministra Nancy Andrighi em relevante voto em outubro de 2010 (já mencionado anteriormente neste trabalho) para o atual cenário de indefinição quanto a forma de reponsabilização dos provedores de Internet oferece a seguinte visão:

"Do quanto exposto até aqui, conclui-se que não se pode considerar de risco a atividade desenvolvida pelos provedores de conteúdo, tampouco se pode ter por defeituosa a ausência de fiscalização prévia das informações inseridas por terceiros no site, inexistindo justificativa para a sua responsabilização objetiva pela veiculação de mensagens de teor ofensivo". ${ }^{164}$ (grifo da autora)

Em sentido contrário à posição da ministra Andrighi, o TJRS, em

${ }^{162}$ TJMG. Ap. Civil. No 1.0091.08.011925-7/001. Rel. Des. Avilmar de Ávila. j. em 07/04/2010.

163 TIRS An Civil No 70039878488 Rel Des Iris Helena Medeirns Nonıleira i em 15/17/7010 
novembro de 2010, em julgamento de recurso inonimado envolvendo a responsabilidade do Google por conteúdo ofensivo postado por terceiros em seus servidores afirma ser de alto risco a atividade desenvolvida pelo provedor de serviços de Internet:

"Ora, é inquestionável que a atividade desenvolvida pela ré Google, com a hospedagem de espaços de divulgação e comunicação de dados pessoais, é potencialmente de alto risco em relação a eventual prejuízo a terceiros, pois é possível, através de dados inverídicos, como no caso presente, a criação de blogs difamatórios, ensejando graves e irreparáveis prejuízos à imagem da pessoa". ${ }^{165}$

No âmbito da doutrina pátria, é comum a busca de refrências no Código Civil italiano para a definição de risco. Dois parâmetros são adotados para definir atividade perigosa (o termo "perigo" é adotado no lugar de "risco"), um quantitaivo e outro qualitativo, são eles: (a) o número de danos causados pela atividade, e (b) a gravidade do dano. Neste sentido observa Tepedino: “A atividade será perigosa, portanto, quando do ponto de vista estatístico, causar danos quantitativamente numerosos e qualitativamente graves". 166

Como resta claro não há consenso na jurisprudência sobre a inserção do risco ou não na conceituação das atividades desenvolvidas pelos prestadores de serviços de Internet. Informação do próprio Google, já mencionada neste trabalho, diz que existem mais de 1.500 processos relacionados à reparação por danos morais em decorrência de atividade ilícita no âmbito no Orkut.

Pela teoria italiana haveria fundamento para se falar em "danos quantitativamente numerosos". Tendo em vista que os danos são em sua esmagadora maioria violações de direitos personalíssimos, talvez houvesse espaço também dentro do mesmo contexto para se falar em "qualitativamente graves".

165 TIRS R I no 71007463453 Rel Des Carlos Fduardo Richinitti I em 09/11/7010 
A escolha dos julgados que apresentados apontam para uma inconsistência existente na jurisprudência a respeito da classificação dos provedores de Internet como atividade de risco, e a consequente responsabilização objetiva em caso de dano ao usuário. 


\section{A Experiência do Marco Civil da Internet no Brasil.}

\subsection{O processo de criação de um marco legal colaborativo para a Internet.}

A indefinição verificada hoje na jurisprudência sobre responsabilidade civil em matéria de redes sociais, juntamente com a crescente adesão desse meio de comunicação digital entre a população brasileira ${ }^{167}$ torna evidente a necessidade de uma regulamentação que estabeleça direitos e deveres inerentes às atividades ali desenvolvidas. A lacuna na legislação gera insegurança jurídica para possíveis investidores ao mesmo tempo em que desestimula a inovação na Internet. Representa também um entrave aos usuários que veem diariamente seus direitos fundamentais violados na rede. ${ }^{168}$

É nesse cenário que surge, em outubro de 2009, a proposta de criação do Marco Civil da Internet no Brasil. A Secretaria de Assuntos Legislativos do Ministério da Justiça (SAL/MJ), em parceria com o Centro de Tecnologia e Sociedade da Fundação Getúlio Vargas do Rio de Janeiro, usou a própria Internet como plataforma para a dicussão do que se tornou, em dezembro de 2010, o anteprojeto de lei que cria o Marco Civil da Internet no Brasil. ${ }^{169}$ Em tempos de web 2.0 a criação do marco regulatório se beneficiou do potencial colaborativo e interativo da Internet e trouxe o tema para o debate público.

\footnotetext{
${ }^{167} \mathrm{http} / / /$ olhardigital.uol.com.br/jovem/redes sociais/noticias/facebook ultrapassa trafego de usu arios do orkut no brasil. Acesso em 04/05/2011.

168 http://info.abril.com.br/noticias/Internet/brasil-e-segundo-em-acoes-contra-google-22092010$2.1 \mathrm{sh} 1$ Acesso em 04/05/2011
} 
O objetivo de usar a própria Internet como principal meio de condução do processo foi no sentido de envolver o maior número de atores que de alguma forma impactam ou sofrem impacto da discussão regulatória no pais. Para tanto foram envolvidos usuários, universidade, iniciativa privada, parlamentares e representantes do governo. A participação no processo de criação do marco regulatório aconteceu por meio do portal http://culturadigital.br/marcocivil, e foi dividida em duas fases.

A primeira fase, com duração de 45 dias, objetivou o debate de temas relacionados à regulamentação tendo como base um documento desenvolvido pelo Ministério da Justiça. ${ }^{170}$ Este documento ofereceu o embasamento do que se pretendia discutir em três blocos de temas: (a) direitos individuais e coletivos, (b) responsabilidade dos atores, e (c) diretrizes governamentais. Cada bloco de tema abrigou subtemas abertos a críticas e sugestões sobre cada um deles. Os comentários eram públicos possibilitando que cada participante, previamente inscrito no processo de criação coletiva, pudesse ter acesso e comentar o que os demais estavam postando.

De especial interesse para o presente trabalho destaca-se o segundo bloco que tratou da responsabilidade dos atores, trazendo inicialmente os seguintes subitens: (a) definição clara de responsabilidade dos intermediários, (b) ausência de legislação específica, (c) um regime de responsabilidade compatível com a natureza dinâmica da Internet, e (d) procedimentos administrativos e extrajudiciais prévios. Pontos que se mostraram em perfeita consonância com o atual estado da jurisprudência que conforme demonstrado anteriormente vem se dividindo em: não responsabilização do provedor, responsabilidade subjetiva, e responsabilidade objetiva. 
A segunda fase do processo de criação do marco regulatório foi realizada tendo como base a minuta do anteprojeto resultante da primeira etapa ${ }^{171}$, e se desenvolveu com as mesmas possibilidades colaborativas e com o mesmo objetivo de estimular a discussão pública de todos os atores interessados no tema. Destaca-se trecho retirado do portal "cultura digital", plataforma especialmente criada para o desenvolvimento do Marco Civil:

"O formato da consulta, em si, pretende estimular a participação da sociedade e reconhecer a relevância de suas contribuições, tanto na definição da abrangência da norma quanto de sua redação final. Busca-se, portanto, ampliar o conceito de participação popular e de democratização do processo legislativo, a partir do uso cidadão de tecnologias de informação e comunicação". ${ }^{172}$

O processo de elaboração do marco regulatório estabeleceu como parâmetro os seguintes princípios que nortearam a estruturação do anteprojeto de lei: (a) liberdade de expressão, (b) privacidade, (c) respeito aos direitos humanos, (d) natureza aberta e dinâmica da Internet. Mais de 2.000 contribuições foram recebidas ${ }^{173}$, e a minuta do anteprojeto de lei resultante da segunda fase foi encaminhada à Casa Civil em dezembro de 2010 onde aguarda o encaminhamento para o Congresso Nacional.

Ao tratar do tema regulamentação do ambiente digital é inevitável a correlação com a quase folclórica "Declaração de Independência do Ciberespaço"174 de John Perry Barlow de 1996. Um momento no qual era comum o pensamento em torno da não interferência jurídica nas questões da rede. Hoje a questão que se coloca é no sentido de identificar a melhor opção de regulamentação, aquela que mais se adequada à proteção dos direitos fundamentais dos usuários, mas também aquela que não emperra o desenvolvimento e a inovação tão característica da Internet. ${ }^{175}$

\footnotetext{
${ }_{171}^{17 t} \mathrm{http}: / /$ culturadigital.br/marcocivil/debate/ acesso em 04/05/2011.

$172 \mathrm{http} / / /$ culturadigital.br/marcocivil/sobre/ acesso em 04/05/2011.

173 http://www2.camara.gov.br/agencia/noticias/COMUNICACAO/192871-CAMARA-DEVEANALISAR-NESTE-ANO-MARCO-CIVIL-DA-INTERNET.html. Acesso em 04/05/2011.

$174 \mathrm{httn} / / \mathrm{www}$ dhnet oro hr/ciher/textos/harlow htm Acesso em 04/05/7011
} 
A proposta de criação do Marco Civil surgiu quando mais de 20 projetos de leis visando a regulamentação da Internet se avolumavam no Congresso Nacional. ${ }^{176}$ Tais projetos tratam de temas específicos sobre o funcionamento da rede, porém um despertava a atenção por objetivar a criminalização de várias condutas realizadas online. Esse projeto (PL 84/99) que estava tendo priorizado seu processo de aprovação representaria para Carlos Affonso Pereira de Souza, "um passo em falso", conforme assinala:

"O Projeto de Lei 84/99 (mais conhecido como "Lei Azeredo") punia com até quatro anos de prisão, por exemplo, a quebra de travas tecnológicas (DRMs), isto é, o desbloqueio de um aparelho celular ou de um aparelho de DVD. O mesmo projeto também previa punir com prisão, por igual período, o indivíduo que passasse as músicas de um CD para o seu computador ou para um tocador de MP3". ${ }^{177}$

O conceito do projeto de lei 84/99 é o oposto da proposta do Marco Civil da Internet no Brasil, visto que o primeiro apresenta cunho restritivo e criminalizante, e o segundo trata de garantir direitos e estabelecer responsabilidades. O PL 84/99 chegou a ser apelidado de AI-5 digital sendo largamente identificado com a prática da censura, conforme Rosemary Segurado observa:

"Entre os pontos polêmicos do projeto, destaca-se o estabelecimento de formas de criminalização dos usuários da Internet, além da obrigatoriedade de identificação dos internautas, aspecto que fere os princípios de liberdade e restringe a privacidade individual e coletiva". ${ }^{178}$

Até março de 2009 a Secretaria de Assuntos Legislativos do Ministério da Justiça trabalhou com foco no referido projeto 84/99. No entanto, graças ao movimento reativo lançado pela socidade civil intitulado

\footnotetext{
${ }^{176} \mathrm{http}: / /$ www.trezentos.blog.br/?p=3763. Acesso em 05/05/2011.

${ }^{177}$ Souza, Carlos Affonso Pereira de et all. Marco Civil da Internet: uma questão de princípio. In: www.nupef.org.br/sites/default/files/poliTICS_n ${ }^{\circ} 7$ _l.pdf

178 Seourado Rosemarv Fntre a regulamentacão e a censura do ciheresnaco P 55 In Revista
} 
"Mega Não"179, o processo de regulamentação da Internet adquiriu outros rumos.

Em junho de 2009 o então presidente Lula em visita ao X Fórum Internacional do Software Livre afirmou que em seu governo "é proibido proibir" já sinalizando que o projeto de lei 84/99 não deveria ser priorizado, conforme afirmou:

"Essa lei que está aí, essa lei que está aí, não visa corrigir abuso de Internet. Ela, na verdade, quer fazer censura. $\mathrm{O}$ que nós precisamos, quem sabe, é mudar o Código Civil, quem sabe seja mudar qualquer coisa. O que nós precisamos é responsabilizar as pessoas que trabalham com a questão digital, com a Internet. É responsabilizar, mas não proibir ou condenar". ${ }^{180}$

Aproveitando a declaração do Presidente da República, e em linha com a noção de que o direito penal é o último recurso, o que se buscou na elaboração do anteprojeto de lei para o marco regulatório da Internet foi priorizar a aplicação dos direitos fundamentais. ${ }^{181} \mathrm{Em}$ se tratando de priorizar direitos fundamentais, é constante a associação de regulamentação com censura, especialmente quando o meio é Internet. Tal preocupação foi externada em alguns comentários críticos a proposta de regulamentação da Internet no Brasil, a exemplo de:

“O Brasil é um estado democrático e não uma ditadura, que precise censurar seus cidadãos. Considero extremamente preocupante a própria iniciativa de criação desta lei. Parece que estamos nos aproximando perigosamente da China. (comentário postado por Cleuton Sampaio de Melo Jr. em 09/04/2010.)

A Lei da Internet quando ela foi concebida é ser uma rede pública e livre, em todos os sentidos. (comentário postado por Tiago de Souza Cardoso em 26/04/2010.)

Sou a favor da autoregulamentação da Internet, ou seja, cada site e ou cada provedor de hospedagem ou de acesso deveriam possuir suas próprias regulamentações, deixando o usuário final livre para escolher aquele que melhor

$179 \mathrm{http} / / /$ meganao.wordpress.com/2009/06/25/o-rio-vai-dizer-um-mega-nao-ao-ai5-digital/ acesso em 05/05/2011.

${ }^{180} \mathrm{httn} / /$ conoressnemfoco $u n l \mathrm{com}$ hr/noticia asn? $\mathrm{cod}$ Canal=18cod Puhlicacan=307).4 
lhe agrade. Este negócio de Marco Regulatório só serve para camuflar ou amenizar a real Censura, seja delegada ou prévia, como infelizmente já estamos vivenciando na imprensa. (comentário postado por Deijivan Hanavan em 17/05/2010)".

Os comentários tornam evidente a preopcupação com a manutenção do princípio constitucional da liberdade de expressão. A redação final do art. 2, $\mathrm{I}^{182}$ do Marco Civil traz esta reafirmação conforme se observa:

Art. 2: A disciplina do uso da Internet no Brasil tem como fundamentos o reconhecimento da escala mundial da rede, o exercício da cidadania em meios digitais, os direitos humanos, a pluralidade, a diversidade, a abertura, a livre iniciativa, a livre concorrência e a colaboração, e observará os seguintes princípios:

I - garantia da liberdade de expressão, comunicação e manifestação de pensamento.

Outro tópico que polarizou opiniões nas discussões da primeira fase do processo de criação de um marco regulatório para a Internet refere-se à necessidade ou não de se criar uma lei específica para Internet. Importa ressaltar que o Marco Civil traz para o ambiente digital soluções legais adotadas em outras áreas do direito positivo brasileiro. Não se trata de uma inovação absoluta, mas sim de adaptar à Internet questões como privacidade e liberdade de expressão, que servirão de parâmetro para a criação de leis mais específicas no futuro. ${ }^{183}$

Vale destacar que se verifica a presença de comentários contrários ao estabelecimento do marco regulatório justamente por considerar que já existe no ordenamento jurídico pátrio leis suficientes para tratar do tema:

"A primeira discussão que deveria ter sido feita era a respeito da real necessidade
da edição de uma lei para regulamentar o uso da Internet no Brasil. (...) o projeto
dispõe de matérias já previstas na Constituição Federal, no Código Civil e no
Código do Consumidor, apresentando-se, portanto inútil a regulamentar
quaisquer dos temas dos quais trata, salvo, talvez, a questão da guarda de "logs",
que em geral pode ser resolvida com a propositura de ação cautelar de

$182 \mathrm{httn} / / \mathrm{culturadioital} \mathrm{hr} / \mathrm{marcocivil} / \mathrm{sohre} /$ acesso em 04/05/2011 
antecipação de prova. (comentário postado por Ronaldo Alves de Andrade em 20/05/2010 14:52)".

Discutir regulamentação de Internet envolve portanto uma ampla gama de fatores que vão desde o repertório jurídico a ser utilizado, questões de infraestrutura e tecnologia, bem como atividades já estabelecidas e aquelas que ainda estão por vir. A compreensão sobre o ambiente de Internet com suas potencialidades e problemas é um ponto relevante no desenvolvimento do Marco Civil, conforme observa Carlos Affonso Pereira de Souza:

"Além de dar concretude a princípio presentes em outras leis, o Marco Civil busca preservar as características da Internet, como a sua natureza participativa, a neutralidade da rede e a interoperabilidade. Trata-se de uma proposta de legislação voltada à Intenet que busca compreendê-la para poder regular seu uso de forma eficaz, sem restringir o seu natural desenvolvimento". ${ }^{184}$

A forma como foi conduzida a criação da minuta do anteprojeto de lei para o marco regulatório da Internet no Brasil é única e inovadora. Não há notícia de outro país que já tenha trabalhado colaborativamente, usando as ferramentas da web 2.0, com a sociedade civil e órgãos do governo para a construção de um projeto de lei. ${ }^{185}$ Ressaltando o ineditismo do projeto de criação do marco regulatório, Rosemary Segurado afirma que: "toda forma de regulamentação da Internet em âmbito nacional deve privilegiar a ampliação, a garantia da liberdade de expressão, manifestação e de organização."186

Um dos artigos da minuta do anteprojeto do marco regulatório que gerou mais discussão é de vital interesse para o presente trabalho. Trata-se do artigo 20 que aborda a questão da responsabilidade do provedor de serviços de Internet. Ao artigo 20, a partir dos comentários gerados na 2a

\footnotetext{
184 Souza, Carlos Affonso Pereira de et all. Marco Civil da Internet: uma questão de princípio. In: www.nupef.org.br/sites/default/files/poliTICS_n ${ }^{\circ} 7 \_$_.pdf

${ }^{185}$ idem

${ }^{186}$ Segurado Rosemarv Fntre a reoullamentacão e a censura do ciheresnaco P 64 In Revista
} 
etapa do processo, foi dada uma redação inteiramente nova. Neste artigo foram postados 143 comentários. O próximo tópico abordará especificamente este assunto.

\subsection{A responsabilidade civil em redes sociais no Marco Civil.}

A responsabilidade civil sobre o conteúdo postado nas redes sociais é tema que mobiliza usuários e provedores de serviços de Internet no Brasil. A indenifição encontrada na jurisprudência, reflexo da falta de regulamentação do assunto, faz com que a insegurança permeie as relações profissionais e pessoais na rede. Com o objetivo de definir responsabilidades e elevar a segurança para todos os atores envolvidos neste cenário há no anteprojeto uma seção intitulada "da remoção de conteúdo" que trata da responsabilidade do provedor de serviços de Internet.

\subsubsection{A antiga redação e suas críticas.}

A primeira versão do artigo 20 causou controvérsia ao responsabilizar o provedor de Internet quando notificado sobre conteúdo ilícito postado por terceiros, que não promovesse a respectiva remoção.

Artigo 20 (redação inicial):

O provedor de serviço de Internet somente poderá ser responsabilizado por danos decorrentes de conteúdo gerado por terceiros se for notificado pelo ofendido e não tomar as providências para, no âmbito do seu serviço e dentro de prazo razoável, tornar indisponível o conteúdo apontado como infringente.

$\S 1^{\circ}$. Os provedores de serviços de Internet devem oferecer de forma ostensiva ao menos um canal eletrônico dedicado ao recebimento de notificações e contranotificações.

$\S 2^{\circ}$. É facultado ao provedor de serviços de Internet criar mecanismo automatizado para atender aos procedimentos dispostos nesta Seção. ${ }^{187}$ 
Como se observa, a redação original do artigo 20 trazia a ideia de notificação extrajudicial, e colocava sob a responsabilidade do provedor fazer a remoção do conteúdo entendido como ilícito por parte do ofendido. As manifestações contrárias foram inúmeras, a começar por aqueles que viram no referido dispositivo uma violação à liberdade de expressão. Marcel Leonardi entende nesse sentido conforme assinala em seu comentário a seguir:

"Creio que a solução apresentada pelo anteprojeto, apesar de ter em mente o direito legítimo de uma vítima de ato ilícito remover rapidamente determinado conteúdo da rede, tem sérias implicações para a liberdade de manifestação do pensamento online. Não creio que se possa prescindir de análise judicial e ordem específica para a retirada de conteúdo, já que decidir sobre a legalidade ou ilegalidade do material - em todas as suas possíveis formas - é algo necessariamente subjetivo, além de ser prerrogativa exclusiva do Judiciário, e não de usuários ou de provedores. ${ }^{188}$ (comentário postado em referência ao artigo 20, em 09/04/2010, grifo da autora)".

A imprensa e usuários também se manifestaram de maneira contrária à redação inicial do artigo 20 do Marco Civil. No blog trezentos, Sergio Amadeu fala em estímulo a indústria da "censura instantânea", conforme observa:

"Entretanto, o artigo 20 obriga um provedor de conteúdo agir como um censor privado. Uma vez acionado por alguém que se diz ofendido, o provedor deverá retirar o conteúdo em questão e depois consultar o seu responsável se o mantém (art. 22). Caso o responsável o mantenha deverá recolocá-lo no site, rede social ou repositório de conteúdos". 189

Uma preocupação recorrente relacionada à notificação extrajudicial é o abuso do direito de notificar em face a argumentos jurídicos inconsistentes para a justificativa de retirada de material. Leonardi afirma existir hoje grande volume de conteúdo controverso mantido online, devido ao entendimento por parte do provedor de que nenhum juiz daria decisão em contrário. Ou seja: seria o caso de retirada de informação que não

\footnotetext{
$188 \mathrm{httn} / /$ culturadigital hr/marcocivil/dehate/ Acessn em 10/05/7011
} 
interessa a determinada pessoa física ou jurídica, mas, não necessariamente ilegal. 190

É recorrente entre os comentários referentes à primeira versão do artigo 20 esta ideia de remoção de conteúdo sem motivos suficientemente relevante, como se assinala abaixo:

"Este dispositivo acaba por negar o direito ao contraditório e a ampla defesa. Ainda poderá ocorrer o abuso do direito em que por qualquer motivo registrem-se notificações pois não cabe ao provedor avaliar o mérito da alegação, gerando verdadeira censura a conteúdo contrário aos interesses, de uma determinada empresa ou pessoa ${ }^{191}$. (comentário postado por Ostrock em referência ao artigo 20, em 09/04/2010, grifo da autora).

Sou leiga na área do direito, só posso me manifestar como povão: o texto do anteprojeto dá margem a zerar todo o conteúdo da Internet em questão de minutos, pois qualquer um poderá pedir que retirem qualquer coisa e na quantidade que bem entender. (comentário postado por Jussara Simões em referência ao artigo 20, em 11/04/2010)". 192

No mesmo sentido a presidente da Associação Nacional dos Jornais $(\mathrm{ANJ})$, Judith Brito, temendo que o marco regulatório represente um cerceamento à liberdade de imprensa, disse em entrevista ao jornal O Globo que a remoção de conteúdo sempre que alguém se sentir prejudicado é prática insconstitucional:

"Isso é frontalmente contrário ao princípio maior da liberdade de expressão consagrado na nossa Constituição. É uma forma evidente de censura. (Deve haver) Total liberdade de expressão, sem a possibilidade de censura, e eventual punição posterior por danos morais quando definido pela Justiça”. 193

Outra voz de peso, o Comitê de Proteção dos Jornalistas (CNJ), também faz coro com ANJ ao criticar a proposta incial do sistema de remoção de conteúdo consubstanciada no artigo 20 do Marco Civil (antiga

\footnotetext{
${ }^{190} \mathrm{http}: / /$ culturadigital.br/marcocivil/debate/. Acesso em 10/05/2011.

191 Idem. Acesso em 10/05/2011.

${ }^{192} \mathrm{http}: / /$ culturadigital.br/marcocivil/debate/. Acesso em 11/05/2011.

193 http://oglobo.globo.com/economia/mat/2010/04/16/marco-da-Internet-sites-jornalisticosnuerem-ficar-de-fora-do-nroietn-do-onverno-nue-reoulamenta-setor-916364403 asn Acessn em
} 
redação), relacionando-a com censura. Chama a atenção para o fato do modelo proposto inicialmente ser prejudicial ao jornalismo online, pois qualquer provedor fará a opção de remover conteúdo apontado como ilícito frente a ameaça real de perder as ações de responsabilidade civil a serem ajuizadas com base na futura legislação ${ }^{194}$.

A sugestão de Leonardi já publicada em obra anterior a discussão do marco regulatório em tela é a seguinte:

"Havendo controvérsia sobre a ilicitude do conteúdo, e não tendo ocorrido violação dos termos de uso do web site, não devem os provedores de hospedagem ou de conteúdo remover ou bloquear o acesso às informações disponibilizadas mas, sim, aguardar a resolução do problema pelo Poder Judiciário, a quem caberá decidir se houve ou não excesso no exercício das liberdades de comunicação e de manifestação de pensamento, violação a direitos autorais ou de propriedade intelectual, entre outras práticas passíveis de lesar direitos alheios, e determinando, em caso positivo, as providências necessárias para fazer cessar a prática do ilícito. Recorde-se, ainda, que tal solução é a que melhor atende aos interesses da vítima, tendo como vantagem não sujeitar o provedor a emitir juízo de valor sobre a licitude do conteúdo, o que poderia causar distorções graves ou decisões arbitrárias". 195

Neste contexto, Ronaldo Lemos oferece solução intermediária localizada entre a ordem judicial e a mera notificação:

"Esse mecanismo pode envolver, por exemplo, a responsabilização de advogado que notifica o provedor mesmo tendo ciência de que sua argumentação jurídica é inconsistente, ou ainda quando a notificação afeta direitos fundamentais, como a liberdade de expressão. Em casos em que a liberdade de expressão possa ser de qualquer maneira afetada, uma solução seria a possibilidade de o provedor manter o conteúdo disponível online, mas com a ressalva de que aquele conteúdo está sendo questionado como violador de direitos". ${ }^{196}$

Desta forma o autor acredita na possibilidade de criação de um real modelo de equilíbrio quando estiverem em jogo direitos fundamentais como a liberdade de expressão. Leonardi aponta ainda que o poder de

194 http://cpj.org/blog/2010/04/is-brazil-the-censorship-capital-of-the-Internet.php\#comments. Acesso em 06/05/2011.

${ }^{195}$ I ennardi. Marcel On Cit n 18 ? 
decidir a respeito da legalidade ou ilegalidade de conteúdo é do Estado, e não cabe a qualquer outro tipo de instituição decidir a este respeito. ${ }^{197}$

\subsubsection{A nova redação do art. 20 (ordem judicial) e comentários relevantes postados no portal colaborativo.}

Após comentários e contribuições recebidas sobre a primeira versão da minuta do anteprojeto de lei para o Marco Civil da Internet no Brasil, a equipe responsável apresentou a redação modificada do artigo 20, ficando assim:

"O provedor de serviço de Internet somente poderá ser responsabilizado por danos decorrentes de conteúdo gerado por terceiros se, após intimado para cumprir ordem judicial a respeito, não tomar as providências para, no âmbito do seu serviço e dentro do prazo assinalado, tornar indisponível o conteúdo apontado como infringente".

Para Marcelo Thompson obrigatoriedade da notificação judicial traz vários inconvenientes, o primeiro e mais grave seria o timing. Pela redação atual do artigo 20 violações a direitos fundamentais tem permissão para permanecerem online até que uma ordem judicial seja emitida, conforme assinala:

“Assumir que qualquer corte pode impedir que o processo (de ofensa, difamação) continue se desenvolvendo é não entender por completo a natureza da Internet. Uma vez aberta a "caixa de pandora", nenhuma corte Herculea poderá fechála. ${ }^{198}$

Thompson também aponta para a previsível sobrecarga que recairá sobre o judiciário brasileiro uma vez aprovado o artigo que exige a ordem judicial para remoção de conteúdo. Usa os números do próprio Google199 para ilustrar a enxurrada de notificações que podem estar por vir. Para ele a

\footnotetext{
${ }^{197} \mathrm{http} / / /$ culturadigital.br/marcocivil/debate/. Acesso em 10/05/2011.

198 Thompson, Marcelo. Op. Cit. p. 4. Tradução livre para: "To assume that any court can prevent the process from developing further is to completely misunderstand the nature of the Internet. Once Pandora"s box is open no herculean court can close it."
} 
redação anterior que previa a suficiência da notificação extrajudicial estava em maior consonância com a proteção dos direitos fundamentais.

O Instituto Brasileiro de Defesa do Consumidor (IDEC) sugeriu a possibilidade de notificação por órgãos autorizados por lei para a defesa do consumidor quando o conteúdo ilícito ou abusivo estiver relacionado às relações de consumo. A preocupação do IDEC com a exclusividade da notificação judicial diz respeito ao descompasso entre o tempo da justiça e o tempo do comércio eletrônico, conforme assinala:

"Considerando que o tempo do comércio eletrônico, desde a sua realização até o acionamento dos atores veiculados para reclamações e resolução de conflitos, é mais ágil que o tempo processual da justiça, a necessária espera de processamento e notificação judicial torna-se um empecilho para a proteção do consumidor. A alteração prevê que provedores retirem conteúdos ilícitos ou ilegais relacionados especificamente às relações comerciais - como contratos com cláusulas abusivas, propaganda enganosa, oferta de produtos ilegais, etc por notificação de órgãos competentes por lei para a defesa do consumidor, como a Fundação de Proteção e Defesa do Consumidor (Procon). A não obediência à notificação de órgãos como esse enseja a responsabilidade objetiva dos provedores que mantiverem o conteúdo". ${ }^{200}$

Outro órgão de defesa do consumidor, a fundação Procon do estado de São Paulo201, também entendeu que a notificação não deveria ficar restrita à ordem judicial, devendo ser estendida ao âmbito administrativo. $\mathrm{O}$ argumento é baseado no artigo 56 do Código de Defesa do Consumidor que contempla a possibilidade de sanções administrativas em caso de infração às normas de proteção ao consumidor:

Art. 56. As infrações das normas de defesa do consumidor ficam sujeitas, conforme o caso, às seguintes sanções administrativas, sem prejuízo das de natureza civil, penal e das definidas em normas específicas:

I - multa;

II - apreensão do produto;

III - inutilização do produto;

IV - cassação do registro do produto junto ao órgão competente;

V - proibição de fabricação do produto;

200 http://culturadigital.br/marcocivil/2010/05/26/contribuicao-do-idec-para-o-marco-civil-daInternet/ acesso em $05 / 05 / 7011$ 
VI - suspensão de fornecimento de produtos ou serviço;

VII - suspensão temporária de atividade;

VIII - revogação de concessão ou permissão de uso;

IX - cassação de licença do estabelecimento ou de atividade;

$\mathrm{X}$ - interdição, total ou parcial, de estabelecimento, de obra ou de atividade;

XI - intervenção administrativa;

XII - imposição de contrapropaganda.

Parágrafo único. As sanções previstas neste artigo serão aplicadas pela autoridade administrativa, no âmbito de sua atribuição, podendo ser aplicadas cumulativamente, inclusive por medida cautelar, antecedente ou incidente de procedimento administrativo.

A polícia federal 202 também se manisfestou favoravelmente a inclusão de outras formas de notificação ao provedor quando for identificado conteúdo ilícito. Sugeriu a validade da notificação policial durante a investigação criminal e a instrução do processo penal.

A ampla notificação extrajudicial é para Marcelo Thompson a alternativa mais adequada à tutela dos direitos presentes nos conflitos que envolvem a responsabilização dos provedores. $\mathrm{O}$ autor propõe soluções jurídicas distintas de acordo com o direito afetado, de forma que os direitos da personalidade deveriam ensejar notificação extrajudicial. Sua posição é, portanto, contrária a formação de juízo do provedor apenas baseada na ordem judicial, conforme observa:

"Nós, que diariamente devemos discernir entre o certo e o errado, pensamos aqui que não deve haver espaço para nosso próprio juízo; que a inafastabilidade do controle jurisdicional é sinônimo de sua imediatidade; que o escopo de atuação da razão das partes deve ser reduzido à inexistência; que a lide deve ser fomentada vez que temos um judiciário competente. Ora, que o nosso judiciário é capaz, que as ondas do Cappeletti se espraiaram, sabemos todos. Presumir nossa incapacidade para escolher nossas próprias razões, porém, é coisa muito diferente. Mais do que confiança no judiciário, reflete a desconfiança em nós mesmos". 203

Marcelo Thompson reforça sua justificativa para a manutenção da redação original do artigo 20, com base seguintes pontos: (a) art. 14 da

$202 \mathrm{http} / /$ culturadigital.br/marcocivil/2010/05/31/contribuicao-da-policia-federal-para-o-marcocivil-da-Internet/ acesso em $06 / 05 / 2011$ 
Diretiva 2001/31 204 da União Europeia, (b) exemplos recentes provenientes do Common Law (Grant v. Torstar Corp ${ }^{205}$, da Suprema Corte do Canadá, 2009 e Jameel v. Wall Street Journal Europe ${ }^{206}$, House of Lords, UK, 2006), que apresentam decisões em favor de uma participação responsável por parte de todos os envolvidos no processo de comunicação, (c) e da "necessidade de se atenuar os chilling effects ${ }^{207}$ " derivados dos mecanismos presentes na diretiva 2001/31 e no Digital Millennium Copyright Act. ${ }^{208}$

Para o referido autor, a redação do artigo que prevaleceu na minuta do anteprojeto dá ao provedor de serviços de Internet uma capa de invulnerabilidade no que tange violações dos direitos fundamentais em tela. Além disso, faz com que os provedores não tenham interesse no desenvolvimento de termos de compromissos capazes de minimizar a ocorrência de atos ilícitos.

No pólo oposto encontram-se os sugestões enviadas por representantes da imprensa (ABERT e ANJ entre outros), conforme já mencionadas neste trabalho, e também de especial interesse os comentários de Marcel Leonardi que protagonizou juntamente com Thompson importante debate por meio da plataforma colaborativa. Leonardi alerta para o fato de que a exigência da ordem judicial privilegia a liberdade de expressão e afirma sua preocupação em sentido contrário ao entendimento de Thompson:

\footnotetext{
${ }^{204} \mathrm{O}$ artigo $14{ }^{\circ}$ regulamenta a armazenagem das informações fornecidas por um destinatário do serviço e armazenadas a pedido de um destinatário do serviço. Assim, a responsabilidade do prestador não poderá ser invocada desde que: o prestador não tenha efetivamente conhecimento de que a atividade é ilícita e, no que se refere a uma ação de indenização por perdas e danos, não tenha conhecimento de fatos ou de circunstâncias que tornem aparente a atividade ilícita; e a partir do momento em que tiver disso conhecimento, o prestador aja imediatamente no sentido de retirar as informações ou impossibilitar o acesso às mesmas.

${ }^{205} \mathrm{http}: / /$ scc.lexum.org/en/2009/2009scc61/2009scc61.html. Acesso em 16/05/2011.

${ }^{206} \mathrm{http} / / / \mathrm{www}$. publications.parliament.uk/pa/ld200506/ldjudgmt/jd061011/jamee-1.htm

${ }^{207} \mathrm{http}: / /$ en.wikipedia.org/wiki/Chilling effect. Acesso em 16/05/2011.

$208 \mathrm{httn} / /$ culturadioital hr/marcocivil/2010/06/01/contrihuican-marceln-thomnson/ acesso em
} 
"E, aqui, reside minha preocupação: um sistema que permita a pronta remoção de informações online mediante simples reclamação do interessado, sem análise judicial, cria espaço para que todas essas reclamações frívolas, que jamais seriam acolhidas pelo Judiciário, sejam necessariamente atendidas pelo provedor, que será obrigado a fazê-lo para se isentar de responsabilidade. (comentário postado em 09/04/2010)".

$\mathrm{O}$ argumento de Marcel Leonardi é recorrente entre aqueles que defenderam a não adoção do sistema de notificação extrajudicial. No entanto, Thompson assinala que a inspiração para o Marco Civil poderia estar na legislação canadense onde sistema é mais moderado do que o "Notice \& Take Down" adotado nos EUA:

"O anteprojeto, ao que me parece, mitiga os problemas do notice-and-takedown do sistema americano. Não há a exigência de que o conteúdo seja removido "expeditiously" (como no DMCA), mas em prazo razoável. Se este for adequadamente definido pelo anteprojeto e somente tiver sua contagem iniciada após transcorrido o prazo para contranotificação, teremos algo que mais se assimila ao sistema do notice-and-notice canadense" 209 .

Outro ponto trazido à discussão por Thompson e Leonardi, que também surge na jurisprudência, diz respeito à ideia de fazer com que os provedores mantenham equipe dedicada a análise da verossimilhança das notificações e contranotificações. Leonardi ressalta que o objetivo do Marco Civil é justamente retirar do provedor qualquer função de análise de conteúdo supostamente ilegal. A contrário senso, Thompson acredita neste caminho até como forma de não sobrecarregar o poder judiciário, e aponta o exemplo da ferramenta de "denunciar abuso" já implantada pelo Orkut. 210

\footnotetext{
${ }^{209} \mathrm{http}: / /$ culturadigital.br/marcocivil/ acesso em 05/05/2011.

${ }^{210}$ Para denunciar uma imagem que esteja violando as nossas políticas, clique em ações na parte superior da página e selecione denunciar abuso no menu suspenso. Nós levamos todas as denúncias a sério quando se trata de fazer cumprir as nossas políticas sobre imagens. Se você tiver denunciado uma imagem e continuar a vê-la no orkut depois de alguns dias úteis, é provável que ela não tenha atendido nossos requisitos para remoção. Se alguém estiver usando uma imagem originalmente enviada por você, sugerimos que entre em contato diretamente com a pessoa que a postou. A menos que a imagem viole nossas políticas, não poderemos remover fotos das quais você não detenha os direitos autorais. http://www.google.com/support/orkut/bin/answer.py?hl=ptBR\&answer=30993. Acesso em 17/05/2011.
} 
Por fim, há o argumento que contrapõe a inovação e o incentivo ao desenvolvimento do mercado de Internet à obrigatoriedade de um monitoramento / verificação da ofensa relatada, segundo observa Leonardi:

\begin{abstract}
"Note que, seja qual for o modelo adotado, é essencial manter as salvaguardas aos intermediários, sejam provedores, sejam usuários moderando conteúdo de terceiros. Proteger intermediários de responsabilidade é algo crítico para preservar a Internet como um espaço para a liberdade de expressão e acesso à informação, apoiando a inovação e o desenvolvimento econômico". ${ }^{211}$
\end{abstract}

Thompson porém, não concorda que o sistema legal deva estar fundado na crença de que o estabelecimento de uma legislação mais protetiva ao usuário seja capaz de estimular a transferência em massa por parte dos provedores de serviços de hospedagem para o exterior. Ressalta que os custos devem ser suportados por aqueles que operam (e lucram) o negócio:

"Faz sentido repartir os custos sociais desse sistema dentre aqueles que não organizam o negócio, ou devemos imputar tais custos aos que o fazem e devem suportar os riscos de fazê-lo dentro de um regime já existente de responsabilidade limitada - o das sociedades empresárias"? ${ }^{212}$

As colaborações de Leonardi e Thompson, entre as de outros pesquisadores, usuários, entidades privadas e governamentais enviadas forneceram o balizamento daquilo que precisa ser regulado hoje. A minuta do anteprojeto está na Casa Civil e aguarda o seu envio para o Congresso, quando finalmente observarevamos quais dispositivos serão mantidos, modificados ou suprimidos.

$211 \mathrm{httn} \cdot / /$ culturadioital hr/marcocivil/ acesso em 16/05/70011 


\section{Conclusão}

O desenvolvimento da Internet como ferramenta de comunicação, entrenimento, aprendizado, e como veículo para a realização dos mais variados tipos de negócios, impõe desafios aos atores que participam desse processo. No mundo jurídico os impactos do progresso são verificados por meio do número crescente de ações ajuízadas relacionadas a conflitos que tem o ambiente digital como palco.

A legislação brasileira não oferece soluções completas para as situações que surgem com a inovação tecnológica, e um dos temas mais controversos hoje diz respeito ao regime de responsabilização dos provedores de serviço de Internet. A jurisprudência se encontra dividida em três correntes como já se viu no presente trabalho: a não responsabilização, a responsabilidade subjetiva, e a responsabilidade objetiva. Os estudos doutrinários também apontam caminhos diferentes para casos similares.

A ausência de legislação específica, que sirva como balizamento para a tomada de decisão não só no âmbito legal, mas também social e econômico, aumenta a insegurança jurídica e impede o amadurecimento do setor como um todo 213 .

Entende-se que descompasso existente entre direito e tecnologia não é em si suficiente para ensejar a criação de novas leis a cada evolução verificada. Porém o estágio no qual se encontra aplicação da responsabilidade social nas formas de uso da Internet 2.0, entre elas as redes sociais, clama por um parâmetro claro capaz de orientar magistrado nos casos concretos.

${ }^{213}$ I emos Ronaldo: et al Resnonsahilidade Civil na Internet uma hreve reflexão sohre a 
Neste sentido já defendia Ronaldo Lemos, em texto de 2005, e portanto muito antes do debate sobre o Marco Civil e a expansão das redes sociais:

"Quando a lei não define objetivamente o equilíbrio desses interesses, como a situação atual, o resultado é que outros fatores passam a ter maior peso no modo como a sua regulação acaba sendo forjada: poder econômico (melhores advogados, mais fôlego para prosseguir com medidas judiciais etc.), circunstâncias de ocasião (o caso ganha atenção da mídia, o caso envolve uma marca famosa etc.), discricionariedade exacerbada do juiz (na ausência de uma diretriz legal clara, o juiz decide como lhe aprouver, valendo-se de sua competência). Portanto, de todas, a ausência de regulamentação é a pior das situações". 214

A experiência do desenvolvimento de um marco regulatório para a Internet brasileira, de forma colaborativa envolvendo atores diretamente impactados nas questões tratadas durante o debate aberto, e posteriormente transformadas em anteprojeto de lei, é sem dúvida um passo positivo na regulamentação da matéria. Agora há que se aguardar o formato final que a lei assumirá após seguir o trâmite de aprovação no Congresso Nacional.

Importa ressaltar que outras questões surgirão na seara das redes sociais, já que é crescente no Brasil e no mundo a adoção destas plataformas por pessoas físicas e jurídicas com os mais varidos fins. Contudo, uma vez definido o escopo de responsabilidades envolvidas espera-se que usuários e provedores encontrem o equilíbrio necessário para que o desenvolvimento de suas atividades possa refletir ao mesmo tempo valores como segurança jurídica, proteção aos direitos fundamentais, e inovação. 


\section{Bibliografia}

ASCENSÃO, José de Oliveira. Direito da Internet e da Sociedade da Informação. Rio de Janeiro: Forense, 2002.

BARBAGALO, Erica Brandini. Aspectos da Responsabilidade Civil dos provedores de serviços na Internet. In: Lemos, Ronaldo; Waisberg, Ivo (Org.). Conflitos sobre nomes de domínio e outras questões jurídicas da Internet. São Paulo: RT, 2003.

BOYD, Dana, \& Ellison, Nicole. Social network sites: Definition, history, and scholarship. Journal of Computer-Mediated Communication, vol. 13 (1), article 11. 2007.

CALIXTO, Marcelo Junqueira. A culpa na responsabilidade civil estrutura e função. Rio de Janeiro: Renovar, 2008.

FILHO, Sergio Cavalieri: Programa de Responsabilidade Civil. Ed Atlas, 2007.

GROSS, R.; ACQUISTI, A. Information Revelation and Privacy in Online Social Networks. In: ACM Workshop on Privacy in the Electronic Society (WPES), 2005. p. 8.

KAPLAN, Andreas M; HAENLEIN, Michael. Users of the world, unite! The challenges and opportunities of social media. In: Business Horizons. Vol 53, Issue 1 (jan-feb 2010) Pp. 59-68.

LEMOS, Ronaldo. Direito, Tecnologia e Cultura. Rio de Janeiro: Editora FGV, 2005 et al.. Responsabilidade Civil na Internet: uma breve reflexão sobre

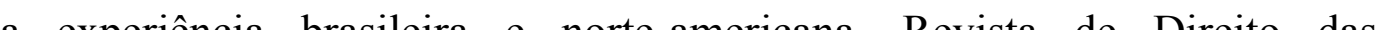


Comunicações - vol. 1. RT: 2010.

LEONARDI, Marcel. Responsabilidade Civil dos Provedores de Serviços de Internet. São Paulo: Editora Juarez de Oliveira. 2005.

LUSK, Brooke. Digital Natives and Social Media Behaviors: An Overview. The Prevention Researcher, 17(December) 2010, pp 3-6.

MARTINS, Guilherme Magalhães. Responsabilidade Civil por Acidente de Consumo na Internet. São Paulo: Editora dos Tribunais, 2008.

MORAES, Maria Celina Bodin de. Risco, Solidariedade, Responsabilidade Objetiva. p. 13. In: Revista dos Tribunais. São Paulo: Revista dos Tribunais. Vol 854, pp 11-37. Dezembro de 2006.

MULHOLLAND, C. Internet e contratação: Panorama das relações contratuais eletrônicas de consumo. Rio de Janeiro: Renovar, 2006.

PALFREY, John et all.. Working Towards a Deeper Understanding of Digital Safety for Children and Young People in Developing Nations. In: Harvard Law School Public Law \& Legal Theory Working Paper Series. Paper No. 10-36. 2010.

PEREIRA, Caio Mário da Silva. Responsabilidade Civil. 9.ed. Rio de Janeiro: Forense, 1998.

PERRY-BARLOW, John. "Declaration of Independece of Cyberspace” In: www.eff.org/pub/Publications/John_Perry_Barlow/barlow_0296.declaratio $\mathrm{n}$ - acesso em 30.03.2011. 
RECUERO, Raquel da Cunha. Em busca de um modelo para o estudo das comunidades virtuais no ciberespaço. In: XXVIII INTERCOM, em setembro de 2005, Rio de Janeiro.

SANTOS, Antonio Jeová. Dano Moral na Internet. São Paulo, Método, 2001.

SEGURADO, Rosemary. Entre a regulamentação e a censura do ciberespaço. P. 55. In: Revista Ponto e Vírgula, 9, 2011.

SLOVE, Daniel. Do Social Network bring the end of privacy? In: Scientific American, Sept. 2008.

SOUZA, Carlos Affonso Pereira de, et all.. "Neutralidade da rede, filtragem de conteúdo e interesse público: reflexões sobre o bloqueio do site Youtube no Brasil", in Revista de Direito Administrativo no 246 (setdez/07); pp.50/78.

SOUZA, Carlos Affonso Pereira de, et all... Marco Civil da Internet: uma questão de princípio. In http://www.nupef.org.br/?q=node/48. Acesso em 25/02/2011.

TEPEDINO, G.J.M..et al.. Código civil interpretado - arts. 421 a 965: conforme a constituição da república. Vol 2. Rio de Janeiro/RJ: Renovar, 2006.

THOMPSON, Marcelo. The Insensitive Internet: Brazil and the Judicialization of Pain. In: http://www.iposgoode.ca/2010/05/theinsensitive-internet-brazil-and-the-judicialization-of-pain. Acesso em 
